\title{
Covid-19 Pandemic-Global Lesson Learnt so far
}

\author{
Fetnani Cecilia
}

\section{Summary}

According to the WHO, as at the 24th of September 2020, there has been 32,083,271 confirmed cases, 981,219 confirmed Coronavirus-related deaths and 23,657,572 recoveries from the disease. The pandemic has so far affected 213 countries and territories around the world and 2 international conveyances. The aim of this review is to identify all the lessons learnt so far with the global management of the current Covid-19 pandemic with the objective of building our global capacity to strategically manage current and future pandemics to enhance global public health. The recommendation moving forwards in the midst of this pandemic seems that we ensure a strong focus on comprehensive testing and surveillance strategies (including isolation and treatment of those infected, contact tracing and quarantining of close contacts of those infected), community measures (including physical distancing and wearing of non-medical face masks in public places), protection and strengthening of healthcare systems, provision of balanced accurate and transparent scientific -based information sharing, meticulous implementation of hand hygiene (hand washing and use of alcohol based hand sanitizers) and avoiding touching the face, nose, eyes and mouth, use of, global collaboration and information sharing, provision of social and economic assistance to the affected and vulnerable in communities, significant investment into national economies, provision of appropriate and adequate personal protective equipment, provision of an enabling environment that front line staff need to carry out their life saving responsibilities, the promotion of mental wellbeing among people living under physical distancing isolation measures and doubling effort at developing a vaccine against Covid-19.

Keywords: Global, lessons learnt, Covid-19, pandemic

\subsection{Introduction}

Coronaviruses belong to a large family of viruses that usually cause mild to moderate upperrespiratory tract illnesses, like the common cold. SARS-CoV-2 PR Covid-19 is closely related to the original SARS-CoV [1]. These viruses are essentially of zoonotic (pigs, camels, bats and cats) origin [2]. Figure 1 shows the schematic diagram of the Coronavirus particle. Three new coronaviruses (SARS-CoV- 1, MERS-CoV and the SARS-CoV- 1) have jump from animal reservoirs (spillover) in the past 20 years to humans causing serious and widespread human disease, illness and death [3]. The SARS coronavirus (SARS-CoV) was responsible for SARS epidemic emerged in November 2002 and caused severe acute respiratory syndrome (SARS). That virus disappeared by 2004. Middle East respiratory syndrome (MERS) is caused by the MERS coronavirus (MERS-CoV). Transmitted from an animal reservoir in camels, MERS was identified in September 2012 and continues to cause 
sporadic and localized outbreaks. The third novel coronavirus to emerge in this century is called SARS-CoV-2 that causes the coronavirus disease 2019 (COVID-19), which emerged from Huanan Seafood Market in Jianghan District, Wuhan, Hubei province of China in December 2019. SARS-CoV-1 or the SARS emerged from China in November 2002 and spread to 26 countries within a few months, affecting 8,000 and 774 death. In September 2012, a new coronavirus (MERS) was identified in the Middle East causing an illness similar to SARS was responsible for 2494 laboratory-confirmed cases of infection with MERS-CoV and 858 MERS-CoV associated deaths. SARS-CoV-2 that causes the coronavirus disease 2019 (COVID-19) [4] which is claimed to have emerged from Wuhan seafood market in Hubei province of China has as at the 15th of June 2016 so far infected 7,997,609 and caused 435,681 deaths worldwide. Community transmission continues to rage in many countries around the globe [5]. However, rumors on social media suggest that the outbreak was humanmade and that the virus may have escaped from a virus lab in Wuhan [6]. The World Health Organization on March 11, 2020 declared it a global pandemic. Unlike the SARS and MERS epidemic, Cocid-19 is posing a global challenge, particularly because of the rapid spread across the globe and the associated high mortality rate. Since 31 December 2019, COVID-19 has affected 213 countries and territories around the world and 2 international conveyances and as of at the 15th of June 2016, 7,997,609 cases of COVID-19 have been reported and sadly 435,681 deaths. The aim of this review is to evaluate the global lessons learnt so far including evidenced -based best practices exhibited by some nations that have successfully contained the spread of the virus that countries currently experiencing a spike can learn from to facilitate the mitigation and containment of the pandemic and that could be implemented in the management of future pandemics.

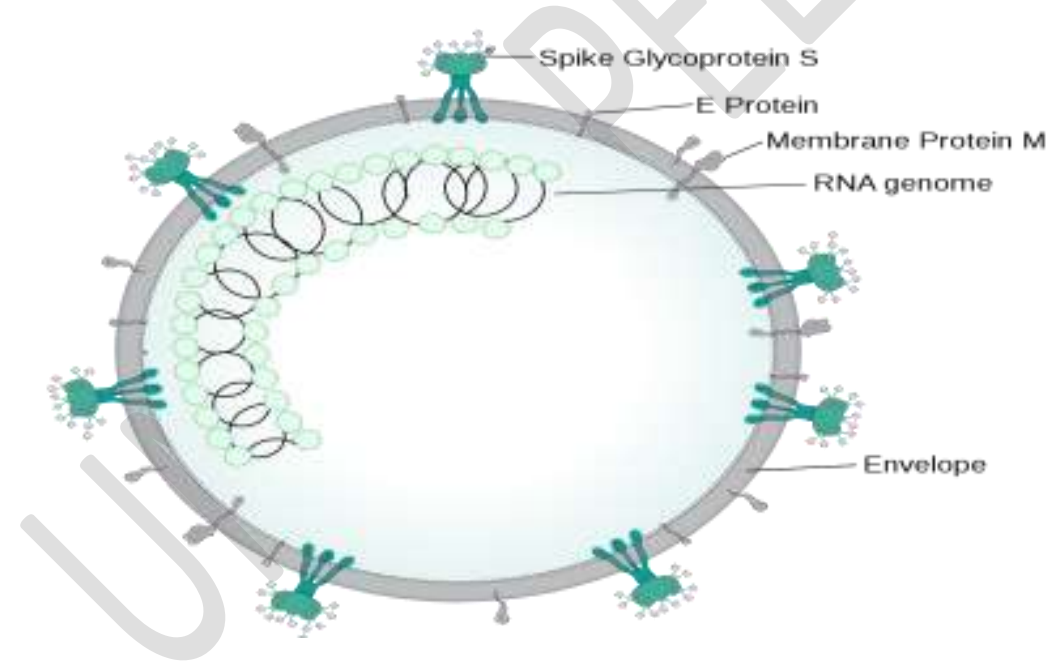

Figure 1: Schematic diagram of the Coronavirus particle (Courtesy of Wikipedia User via a Creative Commons license SPQR10 Binte Altaf)

\subsection{The need to identify patient zero of the Covid-19 Pandemic}

Patient zero or the index case is the first documented patient in a disease pandemic within a population [7]. Patient zero was identified in many past pandemics; Mary Mallon was the index case of a typhoid outbreak in the early 1900s. She was an apparently healthy carrier who went ahead to infected 47 people while working as a cook. She was eventually isolated 
to prevent her from spreading the disease to others [8]. The index patient of the Ebola virus was a 44-year-old schoolteacher named Mabalo Lokela, who died on 8 September 1976, 14 days after symptom onset [9]. Liu Jianlun, a 64-year-old Guangdong doctor was patient zero for the SARS pandemic. He internationally infected other super-spreaders during a stay in the Hong Kong Metropole Hotel in 2003 [10]. Édgar Enrique Hernández may be patient zero of the 2009 flu pandemic [11]. He recovered, and a bronze statue has been erected in his honour [12]. Maria Adela Gutierrez, who contracted the virus about the same time as Hernández, became the first officially confirmed fatality. The Ebola virus outbreak in West Africa which resulted in mortality of more than 4,000 people started with the death of a 2-year-old child from the Guéckédou region of Guinea who died on the 6th of December, 2013. It was not initially clear how the child caught the virus. However, by the 1st of January, 2014, the child's mother, 3-year-old sister and grandmother had all died of the disease. It is suspected that the virus was transmitted for months before the outbreak became apparent because of clusters of cases in the hospitals of Guéckédou and Macenta [13-14]. One-yearold Emile Ouamouno is believed to be patient zero in the 2014 Ebola epidemic in Guinea and West Africa [15]. The first confirmed case of the COVID-19 disease, caused by the SARScov-2 virus, was traced back to a 55-year-old patient in Hubei province, and was reported in a Chinese newspaper on 17 November 2019 [16]. However, a 57-year-old woman, who tested positive for the coronavirus disease on 10 December 2019, and described in The Wall Street Journal on 6 March 2020, may have been patient zero in the 2019-20 coronavirus pandemic [17-18]. Identifying patient zero is important not only for the prevention of future pandemics but also politically. The origin of Covid-19 has already caused a diplomatic row between the US and China as Beijing seeks to shift the blame and liability for the global devastation. There has been claim that the first index case of this pandemic was from zoonotic source to human. The virus is believed to have originated from Huanan Seafood Market in Jianghan District, Wuhan, Hubei, China. However, evidence from the first 42 cases published in academic journals does not seem to support this claim for a number of reasons. Ten of these cases had no history of visiting Wuhan. Also, in early December, although there were clusters of infections in Wuhan, there were already cases of Covid-19 reported in countries like Hong Kong, Japan and Thailand. These patients had no history of ever visiting Wuhan or the Huanan Seafood Market. It seems from an epidemiological point of view that Huanan Seafood Market may not be the source of the index case of patient zero. Identifying patient zero is vital for several reasons; it brings about awareness of an emerging outbreak [19], knowledge could help prevent future pandemics [20], knowing who patient zero is can potentially help researchers and epidemiologists in determining how and when the outbreak started, it determines if they are still alive to facilitate their isolation, treatment and prevention of further spread of the disease, and it facilitates contact tracing to help in the quarantine of close contacts for the incubation period of the infective agent). The knowledge of patient zero or the index case of an epidemic is vital for legal and ethical concerns associated with behavioral approaches by nations to disease containment and mitigation to enhance future pandemic planning [21].

\subsection{The need for prompt autopsy reporting following a Pandemic related mortality}


The severe acute respiratory syndrome (SARS)-coronavirus-2 (CoV-2) outbreak in Wuhan, China has now spread to many countries across the globe with an increasing death toll. Since the outbreak of this pandemic, Scientist and physicians have been faced with many challenges ranging from an accurate determination of cause of death and understanding the pathophysiology that could guide the development of protocol for its effective management. Historically, the autopsy has fulfilled multiple purposes including those pertinent to medical care (diagnostic-related groups, quality assurance, and total patient care), body of medical science (research, education, transplantation, and prostheses), society (public health, vital statistics and forensic issues), and the family (counselling and understanding the life cycle) [22]. Over a long period of time, autopsies also have been a cornerstone for the detection of infectious diseases. It provides an excellent opportunity and important contributions to understanding the pathology and pathogenesis of infectious diseases [23]. Some $20 \%$ to $30 \%$ of infections in hospital patients remain undetected until a post-mortem is performed [24]. For example, in 2005, the entire genome sequence of the $1918 \mathrm{H} 1 \mathrm{~N} 1$ pandemic influenza virus was completed from recovered remains of 1917 influenza pandemic flu victims. This has provided the breakthrough to study the virus in vitro and in vivo and has facilitated a better understanding of its properties, pathogenicity, transmissibility and elicitation of host responses, with major implications for future prevention of subsequent influenza epidemics [25-26]. Over the past century, autopsy has contributed significantly to our understanding of numerous disease processes, but for several reasons, autopsy reports following deaths related to SARS-CoV-2 have thus far been limited across the globe and has affected our having vital clues to the pathophysiology of the disease [27]. Recent findings in the first series of autopsies in the United States report indicate cardiopulmonary challenge as the cause of death from SARS-CoV-2 infection [28]. In general, conducting an autopsy on a patient with a suspected HG3 organism requires four areas of attention: risk assessment, understanding of the pathology that may be found, universal standard precautions and any standard operating procedures for specific HG3 pathogens [29]. Data obtained from clinical autopsies are the most reliable source of information and knowledge about COVID-19related deaths. Performing clinical autopsies in an increasing number of suspected cases worldwide could be useful in tailoring global public health interventions and, possibly, to explain the huge differences in terms of infected cases and disease-related deaths that have been reported in countries particularly those with similar demographic and socioeconomic characteristics. Performing more clinical autopsies and obtaining more information would be extremely important, especially to obtain a reliable description of the distribution of deaths according to gender and age and evaluate the risks of future policies (such as allowing free movement of younger workers to avoid economic collapse). Moreover, data obtained from clinical autopsies are the most reliable source of information and knowledge about COVID19-related deaths [30]. Autopsy examination in cases of COVID-19 infections is vital to understanding the pathological mechanism of this infection. In addition, studies on the corpse will help to understand the survival of the virus after death, better understanding the real dangers for the Forensic Pathologist and for the operators who are in contact with the corpse [31]. A recent post-mortem needle core biopsy of lung, liver, and heart in four patients in Zhongnan Hospital of Wuhan University who died of COVID-19 pneumonia aged 59 to 81 made up of three males and one female with each patient having at least one underlying 
disease, including immunocompromised status (chronic lymphocytic leukaemia and renal transplantation) or other conditions (cirrhosis, hypertension and diabetes). Time from disease onset to death ranged from 15 to 52 days. All patients were observed to have elevated white blood cell counts and lymphocytopenia except for the patient with leukaemia. The postmortem examinations show advanced diffuse alveolar damage, consolidation by fibroblastic proliferation with extracellular matrix and fibrin forming clusters in airspaces as well as superimposed bacterial pneumonia in some patients. Changes in the liver and heart are likely secondary or related to the underlying diseases [32]. Similarly, complete autopsies of 2 SARS-CoV-2 positive individuals who died in Oklahoma from severe acute respiratory syndrome coronavirus in March 2020 indicated diffuse alveolar damage and airway inflammation reflect true virus-related pathology [33]. This report shows the importance of autopsies following a pandemic. In both cases, the diagnosis of COVID-19 would have been missed without an autopsy. Indeed, it is possible that many individuals dying during this pandemic have never been tested for COVID-19, precluding a definitive diagnosis. If the forensic pathologists had stopped at viral testing and had not obtained lung tissue for microscopic examination, the diagnosis of aspiration pneumonia would have been missed. These complete autopsies were therefore critical for confirming viral infection as well as for distinguishing true virus-related pathology from potential confounders.

\subsection{Need for significant investment in Pandemic preparedness}

A pandemic is defined as the occurrence of a disease on a global scale over a very wide area, crossing international boundaries, affecting a large proportion of people around the world. Pandemics are like the wind. They are inherently unpredictable in appearance and severity, and their periodic onset does not serve to reduce the risk of another pandemic caused by a different virus [34]. The unpredictability of pandemics highlights the need to emphasize the need for vigilance, risk assessment and management. It is impossible to anticipate when the next pandemic might occur or how severe its consequences might be. For centuries, novel strains of influenza have arisen to produce human pandemics, causing widespread illness, pain, death, and disruption. There have been four influenza pandemics in the past hundred years [35]. Pandemics, plagues and epidemics have been part of human existence. There are several pandemics that have plagued humanity. They include; the Prehistoric epidemic: Circa 3000 B.C. which occurred about 5,000 years ago and wiped out a pre-historic village in China; the Plague of Athens: 430 B.C. which occurred around 430 B.C. and resulted in the mortality of about 100,000 people; the Antonine Plague: A.D. 165-180 which may have been smallpox, and killed over 5 million people in the Roman empire [36]; the Plague of Cyprian: A.D. 250-271 which was estimated to have killed about 5,000 people a day in Rome alone; the Plague of Justinian: A.D. 541-542 which lead to the death of up to $10 \%$ of the world's population; the Black Death: 1346-1353 caused by a strain of the bacterium Yersinia pestis and wiped out over half of Europe's population; the Cocoliztli epidemic: 1545-1548 a form of viral haemorrhagic fever that killed 15 million inhabitants of Mexico and Central America; the American Plagues: 16th century which led to the death of an estimated $90 \%$ of the indigenous population in the Western Hemisphere; Great Plague of London: 1665-1666 which was associated with fleas from plague-infected rodents which killed about 100,000 people, including $15 \%$ of the population of London; the Great Plague of Marseille: 1720- 
1723 which killed as many as 100,000 people in Marseille and surrounding areas; the Russian plague: 1770-1772 which led to the death of as many as 100,000 people; the Philadelphia yellow fever epidemic: 1793 a yellow fever disease transmitted by mosquitoes which killed more than 5,000 people; the Flu pandemic: 1889-1890 which eliminated about 1 million people in a few months; the American polio epidemic: 1916 with 27,000 cases and 6,000 deaths in the United States; the Spanish Flu: 1918-1920 which led to the death of an estimated 500 million people from the South Seas to the North Pole fell victim to Spanish Flu; the Asian Flu: 1957-1958 which resulted in the death of over a million; the AIDS pandemic and epidemic: 1981-present day which is estimated to have claimed 35 million lives since it was first identified; the H1N1 Swine Flu pandemic: 2009-2010 which infected as many as 1.4 billion people across the globe and killed between 151,700 and 575,400 people; the West African Ebola epidemic: 2014-2016 which ravaged West Africa between 2014 and 2016, with 28,600 reported cases and 11,325 deaths; the Zika Virus epidemic: 2015-present day in South America and Central America [37]. The associated mortality won't be known for several years and now the Covid-19 pandemic first detected in Wuhan Hubei Province of China in 31 December 2019 and as of the 20th of September 2010, there has been $31,446,443$ confirmed cases and Coronavirus-related deaths of 968,234 globally.

From the World Health Organization (WHO) perspective on Influenza, a pandemic is defined as the period of global spread of human influenza caused by a new influenza subtype. There are four levels in pandemic activity (interpandemic, alert, pandemic, and transition) [38]. On average, three pandemics per century have been documented since the 16th century, occurring at intervals of 10-50 years. In the 20th century, pandemics occurred in 1918, 1957 and 1968. The pandemic of 1918 is estimated to have killed more than 40 million people in less than one year, with peak mortality rates occurring in people aged $20-45$ years. The pandemics of 1957 and 1968 were milder (1-4 million estimated deaths, primarily in traditional risk groups such as the elderly), but many countries nevertheless experienced strains on health-care resources. If an influenza pandemic virus were to appear again similar to the one that struck in 1918, even taking into account the advances in medicine since then, unmatched tolls of illness and death could be expected [37]. Several factors ranging from air travel and global mobility of people from one country to the other are major drivers of the spread of a new virus often decreasing the time available for preparing for interventions. Experience even in developed economies from the ongoing Covid-19 pandemic has shown how health-care systems could be rapidly overwhelmed, economies strained, and social order disrupted. It is glaring that it is practically impossible to prevent a pandemic virus, however we can minimize the consequences by learning from mistakes of past pandemics and implementing best practices learnt from fighting past pandemics through advance preparation to meet the challenge. Proactive preparedness, vigilance and prompt alert are keys to effective pandemic management. Evidence has shown from the current Covid-19 pandemic that once a pandemic has begun, it is too late to fully implement new activities that might be required to minimize its impact. The current Covid-19 pandemic with its associated high mortality and economic devastation is a wakeup call for government across the globe particularly developing countries on the need to put system in place prior to the occurrence of a pandemic. It makes economic and social sense for Nations to invest considerable resources 
into pandemic preparedness by developing and exercising pandemic plans (systems, human and infrastructural endowments) and implementing preparedness activities aimed at reducing morbidity and mortality as well as the huge socioeconomic effects of a possible pandemic. Evidence from the current Covid-pandemics indicated that need to consider a number of elements by individual member states of the United nation in pandemic preparedness and post-pandemic evaluation period; adaptability to change in the face of rapidly changing evidence (flexibility); capacity building to mitigate the pandemic; effective communication and information sharing both within nations and among other nations through the WHO, a team global spirit in coordinating the management of the pandemic; governance and leadership (responsibility, accountability and ensuring compliance) and mutual support (provision of assistance, social, human, infrastructural and useful feedback) among all the nations of the earth as part of a global team [39]. There are often 6 phases associated with a health pandemic. There are evidenced- based best practices expected at each of these phases aimed at containing the disease and reducing disease-related mortality. Table 1 shows the phases of pandemic and associated expected best practices.

Table 1: The phases of pandemic and associated expected best practices [40]

\begin{tabular}{ll}
\hline $\begin{array}{l}\text { Phase of a } \\
\text { Pandemic }\end{array}$ & Common Finding \\
$\begin{array}{l}\text { Interpandemic } \\
\text { period Phase 1 }\end{array}$ & $\begin{array}{l}\text { Discovery of an infectious agent } \\
\text { (virus subtype) in animals that } \\
\text { has potential to cause disease in } \\
\text { humans. }\end{array}$
\end{tabular}

Phase 2.

Phase 3.

Phase 4.

Phase 5

Phase 6.

No new virus subtypes have been detected. Minimize the risk of transmission to humans

Human infection(s) with a new subtype without any evidence of human-to-human spread or few instances of spread

Report of a small cluster(s) of human-to-human spread.

A significant larger cluster(s) of human-to-human reported spread Expected Evidenced- Based Best Practices

Manage infection in animals and intensify preparedness for pandemic should the infection cross over to humans

Raise a pandemic alert

Characterize new virus. Monitor human-to-human spread of subtype. Notify close contact.

Contain the new virus. Intensify preparedness testing, isolation, quarantine, treatment and vaccine development

Double efforts to ensure virus is localized to contain or delay spread to possibly avert a pandemic.

Increased and sustained Minimize the impact of the transmission pandemic. 
In the light of the devastation caused by Covid-19 thus far, it is vital to reiterate the need for adequate pandemic preparedness. Evidence based best practice with pandemic preparedness requires: that all national government set aside dedicated budget lines for pandemic preparedness and response; ensure strong leadership and government engagement in pandemic preparedness; develop a process- oriented pandemic preparedness planning that is flexible and adaptable; ensure the development of effective communication channels that keeps all internal (health care professionals, the public) and external stakeholders [regional government (EU, AU, ECOWAS, e.t.c.), WHO and the United Nations] adequately informed; continued strengthening of a multi-stakeholder and multi-sectoral coordination of the pandemic process; development and funding of a think tank, committee, taskforce or pandemic management group or agency; ensure that logistics is in place to facilitate the availability, advance stockpiling (testing kits, equipment, consumables, personal protective equipment and antivirals) that is recycled regularly to prevent outdate, adequate and sustained food supply chain; ensure the protection, safety and optimal and sustained utilization of healthcare workers; ensure that process and infrastructure are in place for containment and treatment activities (isolation, quarantine and ICU capacity) and contact tracing; incorporation of regular exercises, drills and simulations to ensure familiarity of roles among representatives of all stakeholders involved in the pandemic preparedness plan; business continuity plan; ensure there is a dedicated, focal or key governmental spokesperson for disseminating vital information (correct, unambiguous, clear, consistent, and balanced) about the pandemic to the public; put a process in place for the focal health agency of government like the ministry or department of health establishing ways to be able to inform hospital, doctors, general practice or family doctors and other healthcare professionals using existing channels that have been shown over the years to be effective and trusted in balance information sharing (treatment, testing protocols, health and safety requirements, trainings, recommendation of good practice principles, guidance for frontline health care workers, e.t.c.) in a manner that is brief, clear, and tailored to members of the healthcare team (medical laboratory scientist, nurses, pharmacists, clinician, staff in intensive care units (ICU), general practice or family doctors and other healthcare professionals); rational and safe use of limited diagnostic capacity and PPE especially in resource-limited settings and developing economies. All these evidence-based practices are needed to enable nations prepare for future pandemic and for the mitigation of the ongoing Covid-19 pandemic.

\subsection{Zero tolerance for complacency with pandemic reporting and management}

Complacency is defined as a feeling of contentment or self-satisfaction, often combined with a lack of awareness of pending trouble or controversy. Complacency associated with the prompt and accurate reporting of the outbreaks of infectious diseases and pandemic is dangerous and can potentially put the world at risk of infectious diseases and pandemics. Delay or complacency in raising a pandemic alert (reporting of infectious disease outbreak or pandemic) can have far reaching impact and implication judging from the current Covid-19 pandemic. It can have immediate effects of loss of economic productivity, massive strain on health care delivery systems and potentially huge human and material loss and huge 
morbidity and mortality. A "pandemic alert" period is a critical period in pandemic management when rapid, coordinated global and national actions might help to possibly contain or delay the spread of a new virus in human. Prompt pandemic alert allow for a concerted global effort in containing the spread, give other nations and the WHO time to implement other pandemic preparedness measures that had been planned in advance. It has been insinuated in several quarters that there seems some level of complacency with regards to the reporting and earlier management of the current Covid-19 pandemic by several national government across the globe [41].

\section{China}

Like in 2003 with the SARs outbreak, the Chinese government is again on the spot light being heavily criticized for responding slowly and concealing vital information on the seriousness of the Covid-19 pandemic outbreak allowing it to spread all over the globe. Chinese officials have been accused once again of being reluctant to share information during the early stages of the current outbreak, which hampered global recognition of the threat. For weeks, local officials in Wuhan downplayed the seriousness of the threat, reporting that people with the infection had contracted it through exposure to live animals at a market. Unconfirmed evidence from South China Morning Post, said Chinese authorities had identified at least 266 people who contracted the virus last year and who came under medical surveillance, and the earliest case was the 17th of November 2019- weeks before the Chinese authorities announced the emergence of the new virus. There are three possibilities with the delay in China raising a pandemic alert; that cases were not detected at the time; that they were detected but not recognised as a new disease or that they were detected and recognised but reporting was suppressed [41]. On 31 December, 2019, Wuhan Municipal Health Commission, China, reported cluster of cases of pneumonia in Wuhan, Hubei Province [41]. Wuhan's frontline health workers were doing a very good job taking care of the severe cases of atypical pneumonia with unknown causes. They also tried their best to share the information with the Wuhan health authorities. It seems however that this information was not taken seriously by the Chinese authorities. Usually epidemiologists or infectious diseases physicians consider that once there is a cluster of patients in hospitals this only may represent the tip of the iceberg so there may be a lot more people infected within the community. That may have been the reason why some doctors in Wuhan shared this warning to their colleagues but unfortunately the Chinese government did not seem to have taken their concern seriously [41-42]. There has been claim of China's delay in raising a pandemic alert in a timely manner following the outbreak of Covid-19 in Wuhan, China. Evidence from many quarters point to a cover up in the early stage of the pandemic. China has also been criticized for failing to release samples of infected individuals to facilitate the tracing of the evolution of this virus. China's rigid controls on information dissemination, bureaucratic hurdles and a reluctance to send any news that does not put the communist government in good light up the chain of command may have stifled early warnings of a pandemic resulting in a colossal loss of thousands of people all over the world. In the six days after top Chinese officials secretly determined they likely were facing a pandemic from a new coronavirus, the city of Wuhan at the epicentre of the disease hosted a mass banquet for tens of thousands of people; millions began traveling through for Lunar New Year celebrations. On 31 December 
2019, WHO was informed of a cluster of cases of pneumonia of unknown cause detected in Wuhan City, Hubei Province of China. Chinese authorities identified the SARS-CoV-2 as the causative virus on 7 January 2020. Wuhan hospitals in mid-January anticipated prompt total isolation of the city. However, it was not imposed until January 23. But the six-day delay by China's leaders in Beijing came on top of almost two weeks during which the national Center for Disease Control did not register any cases from local officials. Yet during that time, from January 5th to January 17th, hundreds of patients were appearing in hospitals not just in Wuhan but across the country. That delay from January 14th to January 20th was neither the first mistake made by Chinese officials at all levels in confronting the outbreak, nor the longest delay, as governments around the world have dragged their feet for weeks and even months in addressing the virus. Despite the spread of the Covid-19 pandemic not only did the Chinese not raise a pandemic alert and delay in implementing lock down of Wuhan to facilitate containment allowing for unhindered movement of a significant number of people across the country to celebrate the Chinese Lunar new year on the January 25th 2020 may have been responsible for the spread of the virus. This behaviour is seen by many as unethical resulting in the world asking and demanding answers. President Xi Jinping warned the public on the seventh day, January 20th. However, by that time, more than 3,000 people had been infected during almost a week of public silence. It was not until the 23rd of January 2020 (2 days to the Lunar New Year celebration) that the Chinese eventually declared lockdown of Wuhan and quarantined 11 million in Wuhan and over 57 million in fifteen other cities. The Chinese government has been widely criticised over attempts to cover up the outbreak in the early weeks, including crackdowns on doctors who tried to warn colleagues about a new SARS-like virus which was emerging in the city of Wuhan in Hubei province. The Chinese government seem to have initially withheld basic information about the coronavirus from the public, underreported cases of infection, downplayed the severity of the infection, and dismissed the likelihood of transmission between humans. Authorities detained people for reporting on the epidemic on social media and internet users for "rumourmongering," censored online discussions of the epidemic, and curbed media reporting. In early January, Li Wenliang, a doctor at a hospital in Wuhan where infected patients were being treated, was summoned by police for "spreading rumours" after he warned of the new virus in an online chatroom. He died in early February from the virus [42]. There is increasing advocacy that China be made accountable for the poor handling particularly with raising a timely pandemic alert in the early days of the Covid-19 pandemic. Many Chinese are beginning to sue the Wuhan municipal government for allegedly concealing the seriousness of the virus, among other complaints, according to court documents prepared by Funeng, a public welfare NGO based in Changsha. Most Chinese and others all over the world particularly those who have lost loved ones are seeking answers or simply an apology from the Chinese government who took weeks to notify the public of the threat from a virus that have so far claimed the lives of 981,219 people worldwide including 4,634 Chinese as at the 24th of September, 2020 [43]. But the delay by the first country to face the new coronavirus came at a critical time- the beginning of the outbreak. China's attempt to walk a line between alerting the public and avoiding panic set the stage for a pandemic that has infected more than 32 million people and taken more than 981,000 lives. 
In Iran, the Covid-19 outbreak has emerged at a time when the Iranian authorities had severely damaged public trust by brutally repressing widespread anti-government protests and lying about shooting down a civilian airliner. As a result, Iranian authorities have struggled to assure the public that government decision-making around the COVID-19 outbreak has been correct and, in the public's, best interests. The first confirmed cases of SARS-CoV-2 infections in Iran were report on 19 February 2020 in Qom [44]. The Iranian government has been accused of cover-ups, censorship, and mismanagement of the Covid-19 pandemic [45-46]. The Iran government complacently failed to acknowledge the presence of coronavirus in the country until February 19th 2020. The Iranian government was slow to acknowledge the coronavirus outbreak because February 11th is the anniversary of the Islamic revolution and February 21st was already scheduled as date for parliamentary elections. The government was complacent to impose restrictions on either of these public events as it was seen as potentially damaging to a government already under pressure. As a result, on this complacency and failure to report, Iran became one of the worst-affected countries by the Covid-19 pandemic, reporting nearly 1,000 deaths and more than 16,000 cases [47]. Satellite images emanating from Iran has shown the extent of death associated with the virus with workers seen digging mass burial pits for weeks. Public complacency and denial about COVID-19 has led to a disproportionate infection among a number of Iran's elite; senior clerics, government officials and the higher echelons of the Republican Guard. Other complacency-related and failure to act factors driving the epidemic in the Islamic Republic of Iran include; poor implementation of social distancing (the people interact frequently and greet one another with kisses), the nation initially refused to ban social gathering particularly in the holy city of Qom where Shia pilgrims from all over the world continue to congregate in close proximity and American economic sanctions on Iran has also negatively affected the Iranian government's ability to adequately respond to the mounting health consequences of the coronavirus (COVID-19) thus putting a lot of strain on the nation as the government struggles with a shortage of medical equipment and much needed personal protective equipment. According to official reports, as of April 3, 2020, 53,183 people in Iran have contracted the virus and 3,294 have died [48]. However, some outside estimates of the numbers of COVID-19 deaths are much higher than those from government sources, with one estimate of over 40,000 deaths [49-50].

\section{Taiwan}

Taiwan is an island nation considered by China as a breakaway province. The country has a population of over 23 million, recorded the lowest number of cases per million people anywhere in the world over. The island nation is only 81 miles off the coast of mainland China and was generally expected to have the second highest number of cases of Covid-19 cases particularly because of its proximity to and number of flights between it and mainland China [51]. Taiwan is a popular tourist destination. In 2019, 2.71 million visitors from the mainland travelled to Taiwan. Evidence- based best practice management of the Covid-19 pandemic (wearing of protective masks and strictly following other COVID-19 precautions) 
has resulted in one of the lowest Covid-19 cases (441) and death (7) as at the 21st of May, 2020 [52]. The low case count and mortality was achieved without a complete lockdown like in other countries with schools and businesses continuing to operate normally [53]. The first case of the SARS-COV-2 was identified on 21 January 2020, from a 50-year-old woman who had been teaching in Wuhan, China [54]. As of 16th of May 2020, 69,201 tests had been conducted in Taiwan. There are a number of evidenced based best practices that Taiwan implemented that other nations of the world will need to learn from; early preparedness, health expertise, adopted vigorous measures including screening, testing, contact tracing, and enforcing quarantines; proactive, competent and alertness of government exhibited by activating emergency management structures to address the emerging outbreak as well as alerting the World Health Organization (WHO) about the new coronavirus' potential for human-to-human transmission on the 31st of December, 2020 but received no response. Rather the WHO complacently decided to join China's denial of human-to-human transmission until the 21st of January 2020. Taiwan implemented 124 measures including vigorous testing, early screening of flights from Mainland China, strict quarantine measure provided reassurances for the citizens by delivering timely, accurate, and transparent information based on evolving scientific evidence to avoid misinformation, tracking of individual cases and implementation of lessons learnt from the 2003 SARS outbreak to mitigate against the spread of the virus without having to resort to the lockdowns, suspended tours to China, Hong Kong and Macau, foreign nationals were barred from entering Taiwan, ban on the export of face mask before the epidemic had spread to many countries before scarcity globally that led to China (one of the world's top manufacturer) confiscating facemask destined for export to other countries [55], quarantine suspicious cases for 14 days including persons returning to Taiwan from most of Europe including those who transferred through China, Hong Kong, Macau, and Dubai, uses the national health insurance database and integrated it with the immigration and customs database for case identification and tracked travel history and clinical symptoms to distinguish possible COVID-19 victim, promptly allocated resources to protect the public health, acted swiftly following the declaration of Covid-19 pandemic just before the Lunar New Year at a time when millions of Chinese and Taiwanese were expected to travel for the holidays by mobilizing and instituting specific approaches for case identification and containment, announced resource allocation for capacity management and expansion of the stimulus package to NT\$1.05 trillion, controlled entry into the country from the air and sea, formulated policies toward schools and childcare and offered relief to businesses [56]. No wonder Taiwan published GDP for the first quarter of 2020 which saw a growth of $1.52 \%$ year-on-years despite decreasing exports [57-60].

\section{South Korea}

The first confirmed case of COVID-19 in South Korea came on January 19, 2020 [61]. A visitor had arrived at Incheon International Airport from Wuhan, China, and tested positive after being flagged for high body temperature at the entry screening using an infrared sensor. South Korea recognized the threat this outbreak posed to their nation early despite the complacency of China a close neighbour and trading partner. With constant exchange of 
tourists, workers, and academics between the nations, it was inevitable that the virus would enter Korea through a visitor or returning citizen. The emergence of COVID-19 in South Korea, and the public and private sector response to it, serves as a valuable case study for countries facing similar outbreaks [62]. There are two major evidenced- based best practices that South Korea implemented to blunt the exponential spread of the Covid-19 pandemic that other nations such as the US, UK and Brazil currently struggling to contain the pandemic can imbibe [63]. They include vigorous testing (to identify potential asymptomatic carriers and hotspots of the disease) and tracking close and minor contacts of those found positive as well as assigning local hospitals as infection control institutes to preserve medical capacity in case of spike in infection rate. These implementations allowed the nation to function without the need for lockdown [64-65]. South Korea was swift in her response to a surge in the number infection in mid-February that was associated in large gathering in a church in the south-east region. This best practice of prompt identification of the root cause/s and implementation of corrective actions may be useful lessons for countries experiencing a surge in number. South Korea did not implement complete lockdowns like other nations, but rather a travel bans on visitors coming from Hubei, China. This also facilitated the cooperation of the citizens who promptly complied with the government's recommendation on social distancing, cancelling mass gathering, meetings and encouraging employees to work remotely from home. This reduced the anticipated negative impact on economy. Another best practice exhibited by South Korea in the face of Covid 19 was the dissemination of accurate, transparent, balanced and evidenced based scientific information sharing through daily briefing by a responsible government officials (Deputy Minister of Health and Welfare, the Director of the Korean Center for Disease Control, Mayors and governors of major cities and provinces) centred on new cases, mortality, number of people treated, and regional distribution of cases. Transparency in information sharing is key to building the trust of the citizens, establishing public confidence, promoting citizen vigilance and facilitating compliance of the citizens to government policies and recommendations. Trust and transparency are a vital element of social capital particularly in the face of a national health emergency. Instead of very restrictive measures, a policy of extensive tracing was adopted. When a person tests positive, all paths are traced to check where and when a patient visited. This includes checking visited restaurants or modes of transportation (including specific bus or subway routes and lines). The government uses all types of information, such as credit card payment, mobile phones, and closed channel cameras. Text messages are then sent by local and district government to all residents, encouraging those who were exposed to the contacts to self-isolate or get tested, contributing to the reduction of infection. The extensive tracing of contacts can be controversial from a privacy perspective. Businesses may be negatively impacted when they lose customers due to reports that a positive COVID-19 patient has visited a local restaurant or shop. However, the contact tracing was, and still is, widely supported by the public. Contract tracing must be based on social consensus and may not be applied to other countries where personal privacy is a key concern. Another best practice from South Korea's management of the Covid-19 pandemic that nations from the west must learn from is in the area of early and prompt implementation of mass testing. As early as January 2020, the government met and offered contract to local companies to mass produce testing kits. By February, test kits (tools needed to identify those affected and hot spots of the pandemic) 
were rolled out. American Donald Trump and UK Boris Johnson failed to learn from this evidenced based best practice and have had to pay dearly by the significant Covid-related mortality suffered by these Western Nations. Within a six weeks period, South Korea had tested more than 300,000 people testing an average of 15,000 per day. At this same time the Donald Trump USA has tested only 8,500 people and UK Boris Johnson was nowhere near the numbers being tested in South Korea. Covid -19 test is not cheap. It cost an average 150 USD. The South Korea offered this test free of charge for citizens who have travelled abroad and those who are close contacts of Covid -19 positive patients. This is a policy for other nations to implement particularly in nation where laboratory testing is based on out of pocket basis to act as incentive for people at risk and their contact who lack the affordability to present themselves for testing. This aided early detection, self-isolation, treatment and tracing and quarantining of close contacts. South Korea is approximately 99,720 sq km, while United States is approximately 9,833,517 sq km, making United States 9,761\% larger than South Korea while the United Kingdom is about 2.4 times bigger than South Korea. South Korea is approximately 99,720 sq km, while United Kingdom is approximately 243,610 sq km, making United Kingdom 2,44\% larger than South Korea. South Korea implemented a root cause analysis and corrective action-oriented response. The infection of a health care worker in a testing health facility led to the implementation of a drive-through testing facilities to facilitate prompt nationwide testing with reduced potential risk of infections. Many countries have since implemented this evidence-based best practice. With mass testing came a significant number of Korean becoming positive and needing hospital care. Faced with this challenge and the risk of the health system being overwhelmed led to the prioritization of those admitted to hospital beds based on severity with vulnerable patients such as older patients and those with pre-existing conditions as well as those with severe symptoms of COVID-19 prioritized and provided hospital beds while less severe cases were accommodated and managed in sixteen non-hospital treatment centers where patients were monitored by a physician who checked their temperature and respiratory symptoms twice a day. One of the ways to manage a pandemic is to draw from the lessons learnt managing previous pandemics. The painful experience of MERS (Middle East Respiratory Syndrome) in 2015 in which 186 South Koreans were infected and 38 mortality provided an opportunity for better preparedness (significant investment in human and infrastructural development of the health sector) and a more proactive and prompt response (mass production of test kits and associated early detection as well as prompt isolation, quarantine and containment of the virus) to the Covid-19 pandemic by both the government and the public. The government also implemented a rescue plan aimed at providing financial support, voucher and rescue loan programs for vulnerable populations.

\section{United Kingdom}

The first coronavirus case was confirmed in the UK on 31 January 2020. In terms of in terms of pandemic preparedness, the UK is one of the well-prepared nations in the world. In October, 2019 an international review of pandemic preparedness ranked the UK the secondbest prepared country in the world after the US. Ninety devastating days down the line following the outbreak of the Covid-19 pandemic the nation with supposedly the best 
pandemic preparedness plans in the world could not leverage on this ranking and ended up unfortunately becoming one of the most affected country in Europe with 259,559 infected persons, 36,739 deaths as at the 25th of May 2020 and the Prime Minister himself requiring ICU admission for Covid-19 [66]. The nations failed to learn fast from the ugly experience from Spain and Italy. According to the words of a UK -based consultant cardiologist Amitava Banerjee. "We were not humble enough to look at other countries (China, Italy or Spain) and learn a lesson from them and lock down quickly. There are a number of other policy missteps that has led to the suboptimal management of the Covid-19 pandemic by the Boris Johnson lead Conservative government. Ministers seemed to have prepared for a different disease the flu, relied of a well- refined plan and was slow to act when it became evidently clear that the current pandemic wasn't a flu but a different disease in all respect than originally already thought and planned for. The nations emergency pandemic stockpile of Tamiflu and Relenza that planned to be used to protect healthcare workers with plan to get pharmaceutical companies to manufacture more became irrelevant in the face of the Covid -19 pandemic [67]. Unlike in South Korea, where government gave contract to local companies to mass produce test kits and other PPE, the Boris Johnson lead conservative government seems to have turned a deaf ear even when local companies offered to assist with boosting local capacity in PPE production preferring rather to import from China and from other companies outside the UK [68]. The UK health budgets have been cut by $£ 200$ million in recent years [69-70]. This has significantly affected the ability of the NHS to perform optimally. Unlike the UK, other countries in Europe such as Germany have invested significantly in the health sector. No wonder they have done remarkably better than the UK in managing the ongoing Covid-19 pandemic. Over the last few years under the conservative government, there has been a drive to increase efficiency in government spending, ensure prudent and wise use of limited resources, avoidance of waste and reduction of the national deficit national deficit. These austerity policies have had a significant blow on welfare system with attendant effect on the physical, health social and mental wellbeing of the people creating a knock-on effect on the healthcare service delivery [71]. In the UK there has been significant challenge of an aging population. The more aged a population, the more the health needs. As the population's health needs have increased without a commensurate increase in health funding but rather cuts in a claimed bid to use the limited resources prudently and wisely [72]. This imbalance has resulted in the ability of the NHS to meet the increasing health needs of the people. This has also affected the ability of the NHS to manage optimally the ongoing Covid -19 pandemic. Within the last decade, the UK has embarked on an austerity policy with attendant budget cuts for welfare provisions, including social care, mental health and community care [73-74]. Other areas where the UK government failed to live up to expectation with regards the management of the Covid-19 pandemic included; lack of capacity for the implementation of track-and-trace testing, complacency in the part of the Prime Minister who does not seem to have led by example maintaining social distancing as he was complacently shaking hands with people in hospitals in early March, lack of political will as he finds ways to ease the lockdown, failure to implement lessons learnt from the last 2016 simulation, Exercise Cygnus, lack of experience dealing with major respiratory disease outbreak, false confidence that Covid-19 like previous severe acute respiratory syndrome (SARS) and Ebola would likely be contained near their place of outbreak and failure to change course promptly when it 
became glaring and evidently clear that Covid -19 was not the flu they had prepared for and proactively make a shift based on evolving evidence.

Past experience and lessons learnt with managing past pandemic seems to have helped other nations but not the UK. Experience lesson learnt by Taiwan in managing the 2013 SARS seems to have paid off in her management of the current COVID-19 pandemic. Soon after the report of a mysterious pneumonia like disease in Wuhan, Taiwan brought in checks on passengers flying from Wuhan and subsequently implemented 120 best practice measures including strict quarantine, border controls, testing and contact tracing. South Korea endured SARS and has even more recent memories of a fatal coronavirus epidemic, after MERS (Middle Eastern respiratory syndrome) broke out there in 2015, killing 36 people. It began ramping up testing capacity from January, before the disease had arrived in force. At one point the country had the highest number of cases outside mainland China, but its testing and careful contact tracing meant it was among the first and most successful countries in flattening the curve. Experience of managing the SARS pandemic made many nations more confident taking proactive steps to contain the pandemic. In Africa, experience of Ebola seems to have helped Sierra Leone keep cases to just 231 so far. Similarly, countries like New Zealand and Denmark who necessarily had no recent outbreaks of respiratory epidemics had responded fast have kept the number of Covid-19 cases low. The UK seemed arrogant according to Dr Banerjee, who is an assistant professor of clinical data science at University College London. "We thought we had nothing to learn from other countries and thought we were an exceptional case. In fact, we had a lot to learn but didn't take the opportunity." Other areas where the UK seemed to have failed included; slow on making a decisive decision on lockdown?, fund starved public services was ill-equipped to handle a pandemic, the NHS lacked enough intensive care beds, protective equipment for staff and, initially, ventilators were suboptimal, the social care sector was poorly prepared for the pandemic, lack of political will to deal early and decisively with the virus, abrupt shifts in strategy, failure to provide adequate protective equipment for front line medical staff and other key workers, inability to organise testing on a large scale in a bid to fish out infected person and determine the hotspots of the virus and failure to provide a coherent account of its plans to lift the lockdown. The UK prime minister Boris Johnson faced reality recently when he admitted that the UK government did not learn lessons from SARS and MERS, that there was poor pandemic planning and a lack of capacity at Public Health England to detect outbreaks of coronavirus around the country [75].

\section{Italy}

Italy is among the countries worst hit by the coronavirus pandemic. Italy like Spain is a highly social nation with fair weather, densely populated cities, physically affectionate social interactions and large elderly populations. The first case of COVID-19 pandemic was confirmed in Italy on 31 January 2020, when two Chinese tourists in Rome tested positive for the virus [76]. There were a number of factors that drove the COVID-19 pandemic in Italy. First is initial complacency. The first coronavirus case was detected in Italy on the $21 \mathrm{st}$ 
February, 2020. However, it took about three weeks from this time for the Italian government to rise to her responsibility to close all non-essential businesses and place a national ban on unnecessary movements. Had the government acted promptly, several thousands of lives could potentially have been saved. Secondly, overconfidence, false hope and inconsistent messages from public officials, including for domestic political reasons initially diluted the impact of public service announcements about proper hygiene and social distancing. Thirdly, the Italian government seems to have underestimated just how fast the virus could spread and how quickly it could push their healthcare systems to the verge of collapse. Fourthly was the problem of denial. The Italian government seems to have been in denial in their failure to recognize the magnitude of the pandemic, and make decisions in real time, as the crisis was unfolding. Some Italian politicians, including the leader of the centre-left Democratic Party Nicola Zingaretti who was later infected by COVID-19 was seen having drinks in Milan, promoting the idea that Italy's financial hub should continue business as usual amidst a fast evolving and spreading pandemic. Also, Italians themselves took the initial state-ofemergency declarations with scepticism despite warning from scientists of the potential for a catastrophe for weeks. The Italian government was not prompt at showing leadership as there was a poorly coordinated approach to the emergency. Another major failure was the leakage of the news of an impending decree to close Northern Italy on the 8th of March, 2020. This led to massive exodus of potentially infected persons from the more affluent North to the poorer South inadvertently spreading the virus to other regions. Also lack of team work and failure in stewardship between central and regional governors who wanted a quicker and more extensive response did not also help matters [77].

The Italian government has been criticized for their complacency in the handling of the pandemic. On 31 January, the Italian government suspended all flights to and from China and declared a state of emergency. In February, 11 municipalities in northern Italy were identified as hotspots and placed under quarantine. On 8 March 2020, Prime Minister Giuseppe Conte expanded the quarantine to all of Lombardy and 14 other northern provinces, and on the following day to all of Italy, placing more than 60 million people in quarantine [79]. On Jan. 31 , Italy had two confirmed cases of COVID-19. By Tuesday, the 17th or March, it had more than 10,000. The Italian Government and American Donald Trump tried complacency with Covid-19 and both countries are paying dearly for it. Between December 1st and February 5th, a number of direct flights went from Wuhan to Rome (28) and Paris (23) as well as to San Francisco and New York (23). The government in these countries did little or nothing to carry out due diligence on these passengers from high risk Wuhan and to encourage selfisolation of passengers on these flights. Italy is today under coronavirus lockdown and the nation is finding a fragile sense of solidarity after initially being complacent with Covid -19. The Italian prime minister, Giuseppe Conte, has recently announced that the whole of Italy was to be designated a "protected zone", and placed under lockdown as cases of Covid-19 in the country rose to 9,172, with 463 deaths. For the next month, until 3 April, 60 million Italians will be obliged to remain at home, and have been ordered to go outside only for "urgent" work, to attend health appointments or to purchase basic provisions. Bars and restaurants will be forced to close at $6 \mathrm{pm}$, and people have been asked to maintain a distance of a metre from one another in all public spaces. The Italian case paint a clear picture of what 
can potentially happen when a government become complacent and make political blunder resulting from political infighting particularly at a critical time of a pandemic or national emergency. The reactional approach and poor management of the Italian government plans to quarantine an area in the north of the country lead to thousands of people from Italy's worsthit northern areas heading south to relatively poor regions such as Puglia and Calabria (these areas before now have been largely unaffected by the virus). This complacency has have put Italy's health weak, suboptimal and struggling economy and health infrastructure at even more risk [80]. On 11 March 2020, Conte prohibited nearly all commercial activity except for supermarkets and pharmacies [81]. On 21 March, the Italian government closed all nonessential businesses and industries, and restricted movement of people [82]. As of 12 May 2020, Italy had 81,266 active cases, one of the highest in the world [83]. Overall, there have been 221,216 confirmed cases and 30,911 deaths (a rate of 509 deaths per million population) while there have been 109,039 recoveries or dismissals [84]. By 12 May, Italy had tested about $1,741,900$ people [85]. Due to the complacency, failure in stewardship and failure to work as a team with the opposition in the face of the pandemic, Italy became the country with the highest number of confirmed coronavirus deaths by the 19th March. There are several aspects that the Italian government could have done better. Firstly, there were limited numbers of testing. It is feared by, many that the due to the limited number of tests performed, the actual numbers of infected people in could be a lot higher than officially reported.

\section{Spain}

In Spain several factors were responsible for the spread of the pandemic. In the early days of the pandemic, Spain, despite the added advantage of seeing what was happening in Italy, failed to recognize the exponential spread in the critical early weeks of coronavirus introduction into the country. In Spain, the first COVID-19 case was reported on the 31st of January, 2020. The first death occurred on the 13th of February, 2020, but it was not diagnosed until post-mortem was done early March 2020 [86]. On March 8th 2020, the same day a quarantine zone was declared across much of Northern Italy, the Spanish government was encouraging people across the country to take to the streets for International Women's Day protests. At this critical time, 10 people had already died of COVID-19 in Spain and 520 cases had been confirmed. On the day of the massive protests, Spain's health minister held a press conference telling people to stay home if they were feeling ill. In Madrid, Spain's hardest-hit region, 120,000 people packed into the city center to support gender equality. The same day, supporters gathered in crowds as large as 60,000 in dozens of other Spanish cities, as other large events like football games and political rallies continued in full force. Among those who joined the women's march were three Cabinet ministers from the country's leftwing coalition and the first lady who was later diagnosed with COVID-19. Irene Montero, the minister of equality, tested positive just four days after the ill-fated march. All these large gatherings were taking place at a critical point in the pandemic in Spain despite the Mayor of the Italian city of Bergamo describing the February Champions' League football match between Italy's Atalanta and Spain's Valencia as "a biological bomb," [87]. Spain's government has not criticized its decision to promote the massive protests. Despite these failures Fernando Grande-Marlaska, Spain's interior minister failed to take responsibility and 
continued in denial by stating that "this government has no reason to regret anything." Also, another failure in stewardship by the Spanish government was her failure to proactively stockpile medical equipment, tests and personal protective equipment until it was too late. This put health workers as a considerable risk with around 20,000 Spanish healthcare workers becoming infected with COVID-19 [88]. Also, like in Italy, in the week of limbo between normality and declaration of full lockdown, thousands of Spanish people living in cities like Madrid fled to their second residences or hometowns to avoid being quarantined or cooped up in the city. This was a major driver that facilitated the spread of the infection in local communities. Prime Minister Pedro Sanchez did not show good example neither was he a good advocate of social distancing because having been seen on the 9th of March 2020 greeting people with the customary two kisses on the cheek [89]. This seem a very reckless behaviour particularly at a time globally when social distancing was being advocated as a way of limiting the spread off the SARS-COV-2. The failure of the Spanish government to be proactive with the Covid-19 pandemic at the early stages of the pandemic had a huge human, economic and financial cost (the IBEX 35, lost $40 \%$ of its value in less than a month, more than 100,000 people have been temporarily laid off and thousands of small businesses have been forced to shut their doors). At the time Spanish authorities waged a full-fledged war by the imposition of one of the world's strictest lockdowns declared on the 14th of March 2020 expected to last until at least April 25, the disease, has already gone out of proportion and the government had no option than to release its biggest ever financial stimulus (up to $€ 200$ billion or $\$ 220$ billion approximately equivalent to one-fifth of the country's GDP) hoping to cushion the significant economic shock of the pandemic [90].

USA

Trump was slow to effectively respond to the growing pandemic despite being warned early on by several aides and health experts about the need for aggressive action. Between December 1st and February 5th, 2020, several direct flights went from Wuhan to San Francisco and New York. These passengers arrived without any attempt by the USA government to quarantine these passengers. Also, the Trump government was slow to place a travel ban on passengers coming from Wuhan to the U.S. As a result of this failure in stewardship by President Donald Trump, the US became the fifth most likely country to import Covid-19 from China, after Thailand, Japan, Taiwan and South Korea. As of Wednesday March 12, the US had 1,323 confirmed cases of Covid-19, the disease stemming from the coronavirus, and 38 deaths. At this stage, public health officials estimated that millions of people may already have been infected with Covid-19. Government's top infectious disease experts including Dr. Anthony Fauci, director of the National Institute of Allergy and Infectious Diseases and a member of the White House coronavirus task force had warned that complacency and failure to readily and aggressively contain and mitigate this pandemic could increase the number of those infected. However, that same evening, the apparently complacent President Donald Trump addressed the nation from the Oval Office 
downplaying the public health risk of the growing pandemic by saying that the virus was on the brink of disappearing. This was a clear contradiction to the evidenced -based facts and statements of the government's top infectious disease experts possibly to explain out his administration initial slow response to the crisis [91]. In the midst of a looming crisis, there are two reactions that should be avoided. The first is panic/fear and the second is complacency. Faced with the coronavirus epidemic, President Donald Thump had falling into the second. President Donald Thump exhibited complacency to the Covid -19 pandemic in several ways; the government was slow to distribute tests kits meaning that fewer people were being tested at the time of making this complacent comment, less than 8,500 people have been tested in the US while a more proactive South Korea was testing 15,000 per day. South Korea is approximately 99,720 sq km, while United States is approximately 9,833,517 sq km, making United States 9,761\% larger than South Korea. Also, the true picture of the epidemic was not immediately seen because only an insignificant few Americans were being tested. The US president claimed without evidence that the footprint of the virus was small and shrinking and downplayed the coronavirus as something similar to the seasonal flu. $\mathrm{He}$ deceived Americans by his baseless optimism that Americans should be overly concerned about something that would quickly pass (a statement that did not match the reality and evidence from health expert and U.S. public health agencies). The President responded to the pandemic with denial and blaming foreigners. One obvious remedial action taken by objective administrations across the globe in a bid to curtailing the spread of the virus was the banning of large gatherings. However complacent President Donald Trump was busy announcing political campaign in Milwaukee and allowing a number of rock concerts, church services, and festivals to continue to go ahead. President Donald Trump has also been accused of not being a team player in the fight against the Coronavirus by being distractive and racist about the virus. This he did by labelling the Corona Virus Chinese virus. On March 23, Donald Thrump's eldest son, Donald Trump Jr shared a Karate Kid-themed meme of his father beating the coronavirus on Instagram with the caption: "Hahahahaha "The Kung-Flu Kid". These comments are not only insensitive but racist. This kind of joke is unexpected at a sober time when thousands of American Lives are being lost partly to the earlier complacency by the American President. Thump did not seem to have done enough particularly around February when the virus was spreading underground but yet instead of declaring a national emergency, the American President was busy holding large political rallies. Donald Trump seems to be in denial and insensitive to the excellent work the American press have done sensitizing Americans about the virus by accurately and objectively covering the gravity of the pandemic. Rather than appreciate the hardwork and selflessness of these reporters, Trump has taken to name calling, describing them with adjective such as "nasty", "terrible", "keep your voice down" and "You ought to be ashamed of yourself" [92]. In the early stages of this pandemic Donald Trump set unrealistic expectations. However, faced with the true reality of the increasing numbers of Americans being infected and dying had to face reality. Trump's denial in the face of rising cases of the Covid-19 pandemic and expert advice on the pandemic led to biggest stock market one-day crash since 1987's Black Monday crash. In the span of 48 hours, the 73 years old president was compelled to quickly retrace his steps by releasing national emergency funds of $\$ 50 \mathrm{bn}$ to address the Coronavirus outbreak. Reality seems to have set in as coronavirus continues to 
cripple businesses across the US. President Trump is coming to terms with realities on ground by recently signing into law a relief package passed by the House and approved by the Senate to provide free testing, expanded funding for food security programs and paid sick, family and medical leave for workers at companies with 500 employees or fewer. Millions of Americans have now lost their jobs as the coronavirus pandemic continues to batter the economy. In March the jobless rate rose $0.9 \%$, the largest single-month change since January 1975, to 4.4\%. An unprecedented more that 30 million Americans have had no option than to seek unemployment benefits and the numbers are still growing [93].

\subsection{Provision of assistance to vulnerable citizens affected by the pandemic}

Lockdown will only be successful if government around the world provide support for the poor and vulnerable affected by the pandemic. The World Bank Group is prepared to deploy up to $\$ 160$ billion over the next 15 months to support COVID-19 measures that will help countries respond to immediate health consequences of the pandemic and bolster economic recovery. The broader economic program is aimed at shortening the time to recovery, create conditions for growth, support small and medium enterprises, and help protect the poor and vulnerable. There will be a strong poverty focus in these operations, with an emphasis on policy-based financing, and protecting the poorest households and the environment [94]. The Covid-19 pandemic has had a significant effect on families and communities in the midst of the Covid-19 pandemic particularly the vulnerable in society (elderly, family whose bread winners have tested positive and in isolation, those that have lost their jobs, the unemployed and the homeless). There is need for government and local authorities across the world to double their efforts by providing food vouchers to people without a stable source of food, home deliveries of foods rich in vitamins that can boost the immune system to help fight off viruses [95] and financial support during the coronavirus (COVID-19) pandemic [96]. There is also the need to provide support to keep young people locked down at home by providing updated advice and information technology-related support for families to keep young people busy and entertained. Lockdowns associated loneliness, workplace closings, quarantine, isolation and furloughs/layoffs can have mental health related effect to people [97]. Increases in mental health issues following outbreak of a pandemic like Covid -19 is anticipated among the population and healthcare workers who may suffer post-traumatic stress disorders (PTSD) from the numerous horrible and painful Covid-19 related deaths they experienced that may warrant the provision of mental health support and counseling [98-100]. There is also the need for post pandemic mental health assessment for survivors of the Covid-19. Past pandemics have demonstrated that diverse types of neuropsychiatric symptoms, such as encephalopathy, mood changes, psychosis, neuromuscular dysfunction, or demyelinating processes, may accompany acute viral infection, or may follow infection by weeks, months, or longer in recovered patients [101-103]. In times like this the need for solidarity and social compassion cannot be over emphasized. There is also the need to ensure global food security for the world's population in time of lockdown [104]. There is need to ban profiteering, panic buying, illicit trade, hoarding of food products and restriction on the number of items an individual can purchase at a time to ensure food products goes round the population [105]. Implementation of value stream mapping is vital to ensure the proper management of the 
supply chain from farm to dining table [106]. There is need to promote good neighbourliness and community spirit by encouraging people to lend a helping hand by sending text message, making phone calls, video chatting loved ones or neighbors in isolation, volunteering to pick up and deliver shopping, treats, medications and other essentials to vulnerable person ensuring strict social distancing measures are implemented, while taking precautions to keep yourself safes, fundraise for people financially impacted by quarantine measures, rent payment relief for self-isolated people without paid sick leave, sending email and if necessary checking out on elderly and vulnerable neighbors maintaining social distancing, share positive news and acts of kindness with the vulnerable in society including Covid-19 survivors and the bereaved and other safety especially vulnerable person that live alone [107].

\subsection{The need to help vulnerable developing countries to manage the pandemic and all its repercussions}

Up to 44 million people in Africa could come down with the coronavirus and 190,000 will die if the virus is not contained, the World Health Organization said [108]. A new WHO report looked at Covid-19 in 47 countries on the African continent. It said that while the rates of transmission in Africa would be slower than in other parts of the world during the pandemic's first year, COVID-19 in Africa could linger for a long time becoming hot spots of the pandemic. It is worthy of note that although the incidence of the Covid-19 is lower at the moment in developing countries compared to the West, COVID-19 could have more longerterm devastating effect in African countries and other developing countries unless a proactive approach and steps are taken by many governments in these countries. There is need to build capacity to test, trace, isolate and treat (TTIT). Many of the countries in West Africa and other developing countries have suboptimal health infrastructure including the human (healthcare workers) and material endowments (medical equipment and personal protective equipment). There is an urgent need to build medical capacity across Africa and the developing world. There is risk that these fragile health infrastructures being overwhelmed quickly. Unless immediate proactive and preventive actions and steps are taken by the WHO, UN, World Bank and the developed world to help these vulnerable countries, the cost of curbing large-scale outbreak in these countries will likely be costlier than continuing to significantly invest in supporting ongoing preventive measures governments are undertaking to contain the spread of the virus in these nations. It is worthy of note that United Nations is boosting its appeal for aid to help some of the world's poorest countries access the estimated $\$ 6.7$ billion required to effectively fight the coronavirus by these vulnerable nations. Other proactive steps taken so far include the approval \$506 and \$643 million in emergency loans and aid respectively by The World Bank the International Monetary Fund to Ecuador. The nation of Ecuador is one of the worst hit. The Latin American country is grappling with the Covid-19 pandemic. There is need to be proactive and take real step before the flu season starts. There is fear that if the coronavirus outbreak has not disappeared by the start of the usual flu season, or if there is a second wave of COVID-19, it could be a huge challenge for the health system to manage both the Covid-19 and seasonal flu alongside. There are several peculiarities among developing countries; the COVID-19 impact could be far worse than in other parts of the world, developing countries face significant challenges in tackling the 
Covid-19 pandemic because of weak health and fiscal infrastructure and there is need for policymakers to learn lessons and implement evidenced-based best practices from developed countries that have effectively tamed the spread of the Covid-19 pandemic [109]. The COVID-19 death toll is ongoing in most developed countries despite their optimized health infrastructure and significant healthcare workers, equipment and PPE endowment. Developing countries may be dealing with a time bomb with the Covid-19 pandemic. The devastative effect in these vulnerable developing countries is likely to be much worse. There is an urgent need for WHO, IMF, UN and other the developed world to act proactively, boldly, decisively, and promptly to prevent looming catastrophe in Africa and other developing countries. Many African countries were ill-prepared to tackle the Ebola epidemic that erupted in 2014. With COVID-19, the risk is much graver because of a number of factors; it spread exponentially, risk that asymptomatic carriers can spread the virus, constrain of weak healthcare facilities, limited resources, economic and religious and cultural constraints to strict implementation of social-distancing measures. Since Egypt reported Africa's first confirmed case of COVID-19 on February 14, the number of cases has risen to more than 10,000, with Algeria, Egypt, Morocco, and South Africa each recording over 2,000 . The continent's death toll already exceeds 500, implying a mortality rate well above the global average. This high death rate, together with the low number of confirmed cases, may reflect Africa's very low rate of COVID-19 testing. Many African governments have signalled a readiness to respond to the pandemic. But designing measures that reflect reality, and ensuring that they are effective, will be difficult. Under South Africa's national lockdown, for example, the country's most vulnerable social groups are struggling to feed their families, cannot wash their hands regularly because they have no access to clean water, and cannot self-isolate if they live in crowded slums. Other African countries with far less developed social-welfare systems than South Africa faces even bigger challenges. According to the World Health Organization, the continent has just 1.06 nurses and midwives for every 1,000 inhabitants. And current evidence suggests that the belief that Africa's tropical climate will help to suppress the coronavirus is a myth. Researchers at Imperial College London estimates that Covid-19 could result in the mortality of 300,000 people in Sub-Saharan Africa. It is also likely to have a devastating effect on the economy of the region due to lost export revenues, severed supply chains and plummeting demand. To effectively manage this pandemic, African governments must make COVID-19 their top priority, and urgently design and implement an objective, ambitious, evidenced-based and informed policies to combat it. There is need for a resolute national action and commitment irrespective of international support. African leaders and those from other developing countries must learn from the initial mistakes and best practices from countries that have already experienced and effectively managed the pandemic (China, South Korea, Taiwan, Italy and Spain). There is need for collaboration and information sharing, mobilization of health experts (internally and from the diaspora). Indeed, every African government should coordinate action by private and public actors and civil society, but without resorting to force. And while governments should establish wartime-like organizational structures and seek to maximize coordination among national and local agencies, they should not use the crisis as an excuse permanently to constrain or remove individual freedoms. Rather, political leaders should encourage the public to hold them accountable for their management of the public-health crisis, and accept 
checks and balances on government power. Managing the coming economic crisis also will be critical. This means reducing the damage to the most dynamic sectors as much and as early as possible, because more productive activities have bigger spill over effects and are crucial for recovery and large-scale employment. The biggest mistake would be to place all economic activities on an equal footing and try to make everyone happy. Instead, policymakers should focus on export industries, which are vital to ensure foreign-exchange liquidity, ease balance-of-payments constraints, and generate employment. Encouraging services exports and high-value service activities is also critical, as is ensuring affordable food supplies.

\subsection{The WHO need to be more proactive with Pandemic Management}

The WHO has worked so hard in the management of the Covid-19 pandemic. There are however a number of lessons to be learnt to enable a prompt, proactive and holistic response to future pandemics. There has been concern with the WHO acting too late initially with the Covid-19 pandemic despite having reports as early as mid-December 2019 of a mystery virus in Wuhan China. WHO did not seem to be as proactive and did not take prompt actions as quickly as they did for H1N1 or SARS. As at end of December 2019, there was an expectation among epidemiologist that a Public Health Emergency of International Concern would have been announced by the WHO and that some sort of travel ban would have been put in place to curtain the spread of the virus. It was not until the end of January that the Public Health Emergency of International Concern was raised. At this time, 19 countries were already affected with more than 8,000 confirmed cases [110]. After SARS, WHO set up an alert system - Public Health Emergency of International Concern. When there was an H1N1 new influenza in 2009, they announced the PHEIC around one month after the first case, when only three countries were affected. So, there was room to develop rapid diagnosis, prepare anti-viral agents and to develop a vaccine very quickly. For Covid-19, some say the first case was in early or mid-December 2019, but by the time the PHEIC was announced at the end of January with no kind of travel alert. In place, 19 countries were already affected with more than 8,000 confirmed cases, so it was too late [110]. Had the WHO been continuous quality improvement conscious and had taken prompt action as quickly as they did for H1N1 or SARS virus pandemics, it is possible that the Covid-19 pandemic may have been contained and early too. It is vital to note, moving forward that there is no need to be bureaucratic with information about a virus and a disease that has potential to cause the death of millions of people worldwide and cripple global economy. Greater transparency is needed not only from China but all nations of the earth to facilitate the containment of this pandemic.

\subsection{Implementing Evidenced based Best Practices}

\section{Clean and disinfect frequently touched surfaces daily}

In December 2019, reports emanated from Wuhan Hubei, China which reported the incidence of pneumonia of unknown etiology which was later identified as the novel beta-coronavirus, SARS-CoV-2. Human-to-human transmission via respiratory droplets and contact with aerosol infected surfaces are the major ways of transmitting this virus [111]. Recent reports indicated that SARS-CoV-2 can persist on a variety of surfaces from hours to days [112]. 
Previous report by Kampf et al. [113] reported that human coronaviruses can persist for up to 9 days at room temperature. This time can be for up to 28 days for veterinary coronviruses and increase of the temperature to 30 degrees or more reduces coronavirus persistence. One of the precautionary recommendations of the CDC aimed at preventing the spread of SARS$\mathrm{CoV}-2$ is the proper cleaning and disinfection of high-touch surfaces such as door handle and knobs, light switches, counter and bench tops and phone [114-115]. The high need for disinfectants against COVID-19 pandemic has led to consumer shortages of cleaning and disinfection products [116]. Good Laboratory Practice principles and WHO recommends that disinfection and environmental cleaning procedures are performed correctly and consistently. Environmental surfaces must be thoroughly cleaned with water and disinfectant. Using hospital disinfectants such as sodium hypochlorite can be an effective method. Disinfection and cleaning of frequently touched surfaces such as doors, toilets, desks, switches and sinks should be carried out with household disinfectants. Different types of biocidal agents such as alcohols (62-71\% ethanol), $0.1 \%$ sodium hypochlorite, hydrogen peroxide and benzalkonium are applied worldwide for disinfection [117].

\section{The need to develop capacity to work remotely from home}

The outbreak of COVID-19 in Wuhan China in 2019 and the declaration of the outbreak as a pandemic by WHO on the 11th March 2020 has generated a number of challenges warranting a review in the way we run business day-to-day globally. In a bid to control the spread of the pandemic, there have been cases of lockdowns warranting non-essential workers to work from home (WFH) [118]. Also, persons who have had contact with infected persons have had to isolate at home for 14 days. Within such isolation period, workers may be asked to work from home to mitigate the risk of spreading the disease. Access to the right types of technology to allow workers to work remotely from home is critical [119]. As more individuals work remotely from home using computers, laptops and tablets that are unmonitored and using often unsecured home Wi-Fi networks, they are potentially vulnerable to cybercriminals. This mass experiment of WFH has led to a surge in demand for videoconferencing applications such as zoom, goggle meeting, Tencent's WeChat Work, Microsoft Teams, Cisco and Alibaba-owned DingTalk. The outbreak of the Covid-19 pandemic and the declaration of lockdowns in countries around the world, left businesses and workers scrambling for technologies and processes on how to get their jobs done remotely at home away from the office [120]. As a result of this trend, the US company Zoom and other videoconferencing providers, has seen its stocks rise, countering the overall trends of poor performance of other stocks due to the Coronavirus pandemic. There are several advantages (improved productivity, improved love lives, cost effective, greener and environmentally friendly as there is no need to drive, go on the train or bus, family friendly, reduces employee exposure to and spreading of the virus, commute time is cut to zero, reduced cost for petrol, reduced carbon footprint, less physically and mentally stressful) and downsides associated with working from home (intrusive bosses who cannot believe their employees can be trusted to work from home, distraction by family members, difficult to focus, potential for workers to slack off doing personal things and there is difficulty in evaluating effectiveness of workers). Remote working or working from home has become a readily available option 
which many businesses have had to adopt as a result of lockdown associated office closures. Many industries are struggling in the light of the Covid-19 pandemic particularly those where WFH is neither a practicable nor realistic options (travel, entertainment, construction and retail industries). The Covid -19 pandemic is a wakeup call for businesses to strategically begin to look as well as build capacity, developing policies and procedures, acquire relevant digital technologies that allow people to work remotely. Following the outbreak of COVID19 , there is anticipation that working from home may become more widely accepted during and following the aftermath of this pandemic. The Covid-19 outbreak has created an opportunity for companies to re-examine the relationship between companies and employees, and the need to build a corporate culture of virtual and remote working that is flexible and mutually beneficial to both employers and employees. There need to digitise effectively in this period of unpredictable circumstances and global crisis caused by the Covid-19 pandemic. As strict self-isolation measures, introduced to control the spread of coronavirus, force millions of us to work from home [121]. Covid-19 has not only brought about a number of downsides. However, it has brought about a significant change in the life of most workers who now compelled to WFH. These workers were used to daily routine of waking up in the early hours of the day, preparing, commuting for hours to their offices and spending eight or more hours with their colleagues before commencing several hours journey and arriving home late and significantly tired. Businesses in developing countries can learn from the evidenced -based best practice fallout from the Covid-19 pandemic by putting processes in place and acquiring adaptable digital technologies, software and applications that facilitates remote WFH from home by hosting virtual and e-meetings using Skype, zoom and Google Hangouts for their business which can host up to 100 participants in one session and allows screen sharing and text chat along with multiple users being able to appear on screen at one time.

\section{Washing of hands with soap and water often or use hand sanitiser gel if soap and water are not available}

The SAR-COV-2 that causes the COVID-19 is spreading significantly across the globe overwhelming health infrastructures particular in Low to Medium Income Countries (LMICs). Scientifically proven therapeutic agent or vaccine is not currently available. In the light of these realities, preventive measures are the current approach to mitigate and prevent the transmission of the virus [122-123]. One of the very effective prevent options is the washing of hands with soap and water for at least 20 seconds or the use alcohol-based hand sanitiser gel if soap and water are not available [124]. However, frequent hygienization of hands has been shown to possibly generate various changes in skin texture, ranging from the development of cutaneous xerosis (dryness of the skin) up to irritant contact dermatitis (ICD) or, rarely, even allergic contact dermatitis (ACD) [125]. Repeated use of soaps, surfactants, detergents, or solvents for hand washing can lead to chronic cumulative irritant contact dermatitis (ICD) due to their ability to remove skin surface lipids, damage skin proteins, denature epidermal keratin, and even induce alteration of the cell membrane of keratinocytes [126]. The WHO recommends the use of alcohol based (at least $60 \%$ alcohol) as a reasonable 
alternative if water and soap are not available to prevent transmission of Covid-19 [127]. There is advocacy that its use should replace hand washing with water and soap particularly because frequent use of these products has not been shown to be associated with skin dryness and irritation [128]. In these times, it is very important to adapt and promote hand washing habits and culture to ensure efficient protection against the spread of COVID-19 while lowering the risk of skin adverse reactions. WHO recommends the following as hand washing related evidenced-based best practices to prevent the transmission of Covid-19; hands should be washed thoroughly (including fingernails, interdigital web spaces, wrists) for at least 20 seconds, using lukewarm water and soap (after using the toilet, being in public areas, before meals, after coughing or sneezing, and whenever the after touching a potentially contaminated surface and when hands are dirty); rinsing the hands after washing by using gentle manoeuvres to avoid physical irritation to the skin; use of fragrance-free and hypoallergenic products skin moisturizer or hand care products after hand washing to keep the skin hydrated and prevent skin reactions; when soap and water are not available, that the use of alcohol-based hand sanitizers (containing at least $60 \%$ alcohol) is a suitable and effective alternative in destroying the virus, wash hands and apply moisturizer after removing protective gloves and use of topical corticosteroids in persons with highly sensitive skin to prevent dermatitis [129].

\section{Stay at home and self-isolate if they are sick until recovery (except to get medical care)}

At the end of 2019, a new zoonotic coronavirus (SARS-CoV-2) responsible for coronavirus Disease (COVID-19), arose from Wuhan, Hubei Province, China [130]. The virus has spread rapidly and to date has killed 1,083,329 persons and causing over 37,901,595 global cases and 28,463,453 recovered as at $16: 17$ on October 12, 2020 [131]. The most common symptoms of coronavirus (COVID-19) are recent onset new continuous cough, shortness of breath and high temperature $\geq 37.80 \mathrm{C}$. Many Covid-19 infected persons only present with a mild infection often not requiring hospitalization [132]. Infected individuals and those who have had contact with an infected person should self-isolate or quarantine at home for 14 days and avoid going to work (work from home), hospital (except if absolutely necessary particularly if the symptoms get worse or in an emergency), going for a walk, school, or public areas or using public transport or taxis, avoid visitors to your home, limit contact with other people, keep 2 metres distance apart where possible if going outside and wash your hands regularly [133-134]. Confirmed infected persons or those suspected of having Covid19 should encourage people living with them with lowered immunity who are potentially at risk (persons $>70$ years, diabetes, lung problems, immune deficiency and pregnant women) to stay where possible with friends or family. However, if this is not possible, it is vital to keep 2 metres away from each other while avoiding sharing a bed with the infected or suspected person. While waiting at home such individuals can monitor their temperature, get lots of rest, drink plenty of water to prevent dehydration, take antipyretic and pain killers (paracetamol or ibuprofen), take medication like cough syrup to ease a cough, breath slowly and keep your room cool if breathless. The requirement to stay at home is aimed at combating the spread of the disease and protect healthcare workers ensuring that hospitals and health infrastructures do not become overwhelmed [135-136]. 


\section{Use of appropriate personal protective equipment when collecting samples and caring for patients}

SARS-CoV-2 is circulating in the community at high rates; healthcare workers are prone to repeated risk in establishing whether patients and individuals are infected because some Covid-19 infected persons are asymptomatic. Most front-line healthcare works carry out aerosol generating procedures (AGPs) that convey higher risk of transmission. There is a general requirement that healthcare workers should be trained on the safe and effective use of personal protective equipment (PPE) [137-138]. Staff should have access to relevant PPE as dictated by a risk assessment that protects them from infection by SARS-COV-2- a respiratory viral disease. The highest risk of transmission of respiratory viruses such as Covid-19 occurs when carrying out aerosol generating procedures (AGPs) of the respiratory tract. The use of enhanced respiratory protective equipment is indicated for health and social care workers performing or assisting in such procedures [139]. Health and social care workers providing care to patients and individuals who are known to be possible or confirmed COVID-19 cases should wear relevant PPE based on risk assessment. Healthcare organisations are required to carry out risk assessment on healthcare-associated COVID-19 risk and provide appropriate PPE. Such risk assessment should not replace or reduce the ability of the health and social care worker to use appropriate PPE while providing care to patients or residents. Use of PPE, including gloves, aprons, long-sleeved gowns or coveralls, eye protection (goggles or face shields or visor) and fluid repellent facial mask (surgical or procedure mask, or particulate respirators) during aerosol-generating procedures are strongly recommended to reduce the risk associated with transmission of pathogens that causes Acute Respiratory Infections (ARI) [140]. Respiratory virus spread can be prevented by hygienic measures, including hand hygiene, use of relevant PPE with gloves, gowns, eye protection (goggles and face shields/visors) and facial mask (medical masks or particulate respiratory) [141]. Face mask use by the general public for limiting the spread of the COVID-19 pandemic is controversial, though increasingly recommended [142]. The community-wide benefits are likely to be greatest when face masks are used in conjunction with other nonpharmaceutical practices (such as social-distancing), and when adoption is nearly universal (nation-wide) and compliance is high [143]. Public mask is more common in many Asian countries and was been shown to be effective in limiting community spread during the 2003 SARS epidemic [144]. Widespread mask use is a prominent feature of the relatively successful COVID-19 prevention response in Taiwan [145]. Masks have also been suggested as a method for limiting community transmission by asymptomatic or at least clinically undetected carriers [146], who may be major drivers of transmission of COVID-19 [147]. Previous reports suggest that masks may both protect the wearer from acquiring various infections [148] or transmitting infection [149]. The use of medical masks (surgical masks and N95 respirators) among healthcare workers appears to consistently protect against respiratory infection under metanalysis [150]. European Centre for Disease Prevention and Control recommend that the use of non-medical face masks in the community should be considered only as a complementary measure [151]. Also medical face mask should be considered as part of personal protective equipment by healthcare workers to protect healthcare workers from Covid-19 infection [152-153]. Face masks can protect against both 
coarser droplet and finer aerosol transmission, though N95 respirators are more effective against finer aerosols, and may be superior in preventing droplet transmission as well [154]. The size of the coronavirus-shaped spherical particles is estimated to be about 0.125 microns $(125 \mathrm{~nm})$ using an electron microscope. The smallest of these viruses are 0.06 microns and the largest are 0.14 microns [155]. The main aim of using a mask is precautionary to protect persons caring for patients with respiratory infections [156]. There are several types of mask (surgical, FFP1, FFP2, N95, FFP 3 and N100). The term FFP stands for 'filtering facepiece'. Masks are categorised based on their percentage abilities to remove or wade off very small particles about 0.3 micron. Surgical masks have the least protective properties (filter $80 \%$ of particles about 0.3 micron). It protects vulnerable patients from doctors and health care professionals. It can also protect the wearer against large droplets and sprays [157]. FFP1, FFP2, FFP3, N95 and N100 masks are capable of filtering 80\%, 94\%, 99.95\%, 95\% and 99.97\% particles about 0.3 micron respectively. Although there is no scientific evidence that masks are protective against SARS-CoV-2, but there is increasing advocacy for its use believing that it may potentially reduce the spread of the virus from the infected patient. An N95 mask is a type of respirator which filters out at least $95 \%$ of very small particles $(0.3$ micron). N95 masks should ideally be used in healthcare facilities by healthcare workers to serve as a barrier to protect workers in direct contact with patient particularly those with infectious respiratory diseases that are transmitted through droplets [158]. There is need for the review on the safe usage of these masks by healthcare workers who are working in the front line in places like ICU and HDU who have to wear these masks continuously or intermittently for 8 hours [159]. There have been reports of allergic reaction and hypoxia [160]. Hospitals may need to require healthcare workers to take regular breaks and rest warranting the removal of the mask to reduce the incidence of hypoxia associated with the continuously use for 8 hours. FFP2 respirator is a filtering face piece 2 (FFP2) respirator filter out at least $94 \%$ of very small particles $(0.3$ micron). FFP2 or N95 are the gold standard to protection against very small particles [161-162]. In this era of the Covid-19 pandemic, there is need to ensure the availability of facemasks and respirators to facilitate compliance and safety of frontline healthcare workers [163]. The use of facemasks is a recommendation to prevent diseases that are potentially transmitted through droplets and respirators for respiratory aerosols [164]. In some countries, it is mandatory to wear a mask as a way of mitigating the transmission of SAR-COV-2. The World Health Organization (WHO) recommends that healthcare workers should medical masks when managing patients with Covid-19 [165]. Covid-19 infected individuals with symptoms should wear a medical mask, self-isolate, and seek medical advice as soon as possible. Masks are also recommended for those caring for Covid-19 patients at home even if they are asymptomatic. Although recommended, there is no scientific evidence that wearing a mask (medical or other types) in the community setting can prevent infection with respiratory viruses, including COVID-19, in a healthy person [166]. The Centers for Disease Control and Prevention recommends that homemade cloth face coverings can be worn in public settings where social distancing measures are difficult to maintain (pharmacies, supermarkets), especially in hotspots where there is evidence significant community transmission [167]. However, there is no evidence to support this [167]. Use of a mask alone is insufficient to provide adequate protection, and they should be used in conjunction with other infection prevention and control measures such 
as frequent hand hygiene and social distancing. It is important to wash your hands with soap and water (or an alcohol-based sanitiser) prior to putting on a face mask, and to remove it correctly. Used masks should be disposed of properly [168-169]. Standard surgical masks are as effective as respirator masks for preventing infection of healthcare workers in outbreaks of viral respiratory illnesses such as influenza, but it is unknown whether this applies to COVID-19 [170]. A small study found that surgical and cotton masks are ineffective at preventing viral spread to the environment from the cough of patients with COVID-19 [171172].

\section{Immunity passports}

Immunity passport is a digital or physical document certifying that an individual has been infected and has developed IgG antibodies against the SARS-CoV-2. Individuals with IgG antibodies against Covid-19 are a proof of immunity against the disease (immunity passport). It is hoped that persons carrying this immunity passport could be exempt from physical distancing restrictions and could travel freely without Covid-19 prevention restriction, return to work, school, and daily life. There is general expectation that persons in possession of these immunity passports would enjoy a greater range of privileges in the face of the ongoing Covid-19 pandemic (education, travel and work). Many governments across the globe are looking for safer, feasible, scientific and ethical alternatives out of restrictive social distancing measures imposed to control the spread of SARS-CoV-2 particularly while waiting for a protective vaccine against COVID-19 [173]. One proposal that some countries (Chile, Germany, Italy, the UK, and the USA) are hoping to implement the immunity passport [174]. It is still early days yet with Covid-19 particularly from the perspective of fully understanding the immunology of the virus. There is paucity of evidence about the effectiveness of antibody-mediated immunity against Covid-19 to guarantee the accuracy of the universal implementation of immunity passport [175]. There is also paucity of scientific evidence to prove that people who have recovered from COVID-19 have antibodies that can protect them from a second infection There are several challenges associated with the implementation of immunity passport; lack of public support for these measures, potential for discrimination of groups of people, potential exist for testing errors resulting in a false positive and negative result, prone to implicit bias, access to testing, prone to fraudulent activities, legal and ethical implications, could impose an artificial restriction on who can and cannot participate in social, civic, and economic activities and risk of people getting infected intentionally in order to obtain a certification [176]. Many advocates of immunity passports have compared it to the international certificates of vaccination (Carte Jaune) for yellow fever. There are however differences between yellow fever vaccination certificates and Covid-19 immunity passport. While the former is good and incentivise individuals to obtain vaccination against the virus, the later incentivise infection. The possible option will be a requirement particularly once a vaccine is developed for people to carry COVID-19 vaccination certificates. This requirement may become included in revised WHO recommendations for the COVID-19 PHEIC. There are however suggestions and advocacy, in the absence of a protective vaccine that decisions to ease physical distancing restrictions at the community level based on use of immunity passport is likely to be more effective if 
implemented in combination with other public health approaches like use of face mask and maintenance of other prevention measures including vigorous testing, contact tracing, quarantine of contacts, isolation of cases and other preventive measures already being implemented [177].

\section{Smoking cessations}

The number of cases of Covid-19 has nearly reached more than four million around the globe, yet there is still a significant amount unknown about the virus. One of such unknowns is whether smoking and vaping increases the risk of contracting Covid-19 and whether smoking has any negative effect on prognosis of Covid-19 infected patients. According to Dr Michael Matthay, the associate director of critical care medicine at the University of California San Francisco (UCSF), the answer is yes - although it is not currently known to what extent [178]. Evidence from prior studies indicates that abstaining from tobacco smoking is likely to lower the risk of respiratory infections and pneumonia [179-181]. Indeed, ex-smokers have a lower risk of pneumonia than current smokers, irrespective of age [182]. Despite millions of regular EC users, there has been no evidence of new emerging pneumonia outbreaks in recent years, or reports of infectious pneumonia in the medical literature. However, we are aware of a case of lipoid pneumonia that respiratory physicians in the United States have suggested being a direct consequence of vaping [183]. Electronic cigarettes (ECs) often consisting of a battery and a heating element that vaporizes a solution (e-liquid) often made up of propylene glycol, vegetable glycerin, distilled water, and different flavors that may or may not contain liquid nicotine. They seem an attractive long-term alternative nicotine source and a possible substitute for cigarette dependence that may minimize residual health risks associated with cigarette smoking. However, a previous report that exposed mice to EC vapour for 2 weeks, followed by pneumococcal infection indicated EC-exposure related increased pneumococcal colony forming unit counts in both the airway and lung tissue [184]. Coronavirus (COVID-19) is a respiratory infection that affects the lungs and airways. Since smoking damages the lungs and weakens an individual's immune system, there is a potential that the hand-to-mouth action of smoking could potentially increase the risk of contracting Covid-19. Past or current smokers have double the risk for severe disease, and smoking cessation should be encouraged [185]. There is also the question as to whether people who smoke are more likely to have severe complications if they get coronavirus? There is paucity of data on whether smoking predisposes to Covid. However, data emerging from the countries first affected by Covid-19 may give a clue. In China, about 8 per cent of people in hospital with covid-19 were smokers, while 26 per cent of the general population smokes. Similarly, in Italy 8 per cent of people in hospital with covid-19 were smokers while 19 percent of the general population smokes [186]. There seems some evidence from smokers admitted in hospital with coronavirus who were observed to be more likely to get severe complications than non-smokers. Smokers may be prone to severe COVID-19 infections, in part, because their lungs contain an abundance of entry points that the virus can exploit [187]. A previous report involving more than 1,000 patients in China, indicated that smokers with COVID-19 were more likely to require intensive medical interventions than those who didn't smoke. In the study, $12.3 \%$ of current smokers who were 
admitted to ICU, were placed on a ventilator or died, as compared with only $4.7 \%$ of nonsmokers [188]. Similarly, smokers are more likely to transmit the virus because their fingers can potentially be contaminated from regular contacts with their lips. Recovery in smokers who already have lung disease or reduced lung capacity is likely poorer than nonsmokers with optimum lung function or capacity [189]. Also, individuals suffering from disease conditions associated with increased oxygen needs or reduce ability to use it properly have an increased risk and poor prognosis from a serious lung conditions such as pneumonia and Covid-19 [190-191].

\section{Development of capacity for testing and diagnosis}

The recommended diagnostic test method for SARS-CoV-2 infection is viral RNA detection with nucleic acid amplification tests (NAAT), such as RT-PCR [192]. The specimen types to be collected for testing are listed in WHO's laboratory guidance [193]. RT-PCR with a Ct value less than 30 is considered a good source of sequencing material. RT-PCR is the current test methodology applied in EU/EEA Member States. However, these tests require wellequipped laboratory facilities, highly skilled medical laboratory scientists or biomedical scientists and multiple reagents. Due to the infrastructure limitations and supply shortages, reliable rapid diagnostic tests for COVID-19, in particular rapid antigen or RNA detection tests could alleviate the pressure on medical laboratories and expand testing capacity to meet the most urgent medical and public health needs. Rapid tests may provide results in 10-30 minutes, they are relatively simple to perform and interpret and therefore require limited test operator training. They may be intended either for use in hospital laboratories or near the point-of-care. SARS-CoV-2 antibody detection tests have limited usefulness for early COVID-19 diagnosis as it can take 6-15 days after onset of symptoms for patients to become positive for detectable antibodies. However, the tests can be used for diagnosis of patients with delayed presentation to hospitals or retrospective diagnosis of milder cases. Once validated, commercial SARS-CoV-2 antibody tests will be essential for performing largescale sero-epidemiological population surveys, for assessing the immune status of first-line responders and healthcare personnel and for guiding safe return to work as part of deescalation strategies when transmission begins to abate. Collecting paired serum specimens at symptom onset, at admission, during the convalescent stage, or upon discharge will be useful for subsequent testing in seroepidemiological studies. Sera biobanking should be undertaken, particularly for hospitalised patients and during outbreaks in schools or confined facilities. WHO has provided several different types of protocols to study immune response in the population and in targeted groups [194].

\section{Contact tracing}

Contact tracing is a core public health measure that plays an important role in the control of COVID-19 [195]. There is increasing evidence that the adoption of rigorous testing and contact tracing can change the trajectory of the outbreak in all transmission scenarios. Countries should adapt measures based on a regular review of their local epidemiological 
situation and available resources. For countries that have implemented strict physical distancing measures to interrupt the chain of transmission of the virus, contact tracing will be a major part of the public health response after these measures are lifted, to reduce the risk of further escalation and community transmission. Before de-escalation measures are implemented, countries should review existing systems to determine the optimal implementation of an effective contact tracing strategy. Several countries in Asia have been able to limit the size of their outbreaks and avoid overwhelming healthcare and high numbers of deaths through intensive contact tracing and quarantine measures [196-197]. Contact tracing in China and Singapore reduced the time from symptom onset to isolation substantially, thus reducing the likelihood of ongoing transmission [198-199].

\section{Maintain social distancing}

Social distancing (physical distancing) is a term used to describe keeping space between yourself and other people outside of your home. From a Covid-19 point of view, to practice social or physical distancing: maintain at least 1 metre ( 3 feet) distance between yourself and anyone who is coughing or sneezing, do not gather in groups or stay out of crowded places and avoid mass gatherings. The reason for maintenance of social distance is to prevent the spread of Covid- 19. Evidence has shown that when someone coughs or sneezes, they spray small liquid droplets from their nose or mouth which may contain the virus. If a person is too close, you can breathe in the droplets, including the COVID-19 virus if the person coughing has the disease [200]. Past experience shows that one consistent response to epidemics has been to decrease social mixing and increase social distance by such means as community restrictions and voluntary social separation [201]. Thus, societies faced with pandemics have often closed public places (schools, childcare, workplaces and mass transit) and cancelled public events (sports, arts, conferences). As fear rises, the public itself may shun public gatherings. Predicting the effect of policies to increase social distance is difficult, as infected persons and their contacts may be displaced into other settings, and individuals may voluntarily separate in response to perceived risk. For these reasons, additional research needs to be conducted on behaviour during epidemics and the effects of social distancing on transmission. Social separation, particularly for long durations, can cause loneliness and emotional detachment, disrupt social and economic life, mental health issues, depression and infringe individual rights [202]. Community restrictions raise profound questions about the government's right to interfere in such areas as faith (for instance, limiting religious gatherings), family (restrictions on funeral attendance), and protection of the vulnerable (restriction from visiting vulnerable individuals and providing them with food, water, clothing, or medical care). One fear is that governments might put into effect restrictions on personal liberties that are unnecessary, implementing restrictions before they are needed, extending them past the end of the crisis, or enacting restrictions that do nothing to decrease disease transmission [203]. It is vital that government across the globe must ensure that shutdown and closings are implemented based on evidence and appropriate standards to ensure necessity, proportionality and prevent infringements of people's rights. It is vital to consider that such closure has a negative cost and distributive-justice implications with a 
higher burden felt often by people with limited resources [204]. Social distancing implementation must be implemented without any discrimination, scapegoating, undue targeting of ethnic or religious minorities and as a pretext to crackdown on opposition or civil societies. Nations should have laws on who has the power to order social distancing strategies, the circumstances, criteria and for what period of time. Governments should also clearly state penalties for those who contravene such policy. The penalties however should be proportional to offenses and not excessive. Social-distancing policies should be implemented fairly and with as broad involvement in planning as possible [205]. This will ensure that the policies are appropriate, enjoy public acceptance, ethical and will not infringe on the fundamental rights of citizens [206-207].

\section{Workplace and School Closings}

Workplace and school closings present particularly difficult ethical issues. Apart from the uncertainty of their effectiveness, the most important issues center on the subject of distributive justice. Workplaces are vital to the livelihoods of both employers and employees, so closing them can cause severe financial hardships. In extreme cases, lost profits caused by closings may push companies to go out of business, leading to job losses and other economic hardships. Even for people who have an economic safety net, these problems can have a significant effect, but for people living at a subsistence level including those on zero hours contract, the effect of lost income can be far worse. If workplaces stay closed for a significant amount of time, such people may be unable to pay their rent or mortgage, food, or medicine. Health officials taking the decision to close schools must carry out a cost benefit analysis and should weigh the potential health benefits of reducing transmission and thus case numbers against high economic and social implications, difficult ethical issues, and the possible disruption of key services such as health and social care [208]. Social distancing may have some health benefits of prevention of disease transmission. There is however debate as to its effectiveness as well as the need for national policy based on evidence to guide when, how and for how long school closure should last [209-210]. Recent reviews highlighted the lack of evidence for social distancing measures such as school closure [211-212]. There is some limited evidence that school closings do reduce seasonal influenza transmission [213-214]. Similar issues are raised by school closings, which may require parents to stay at home in order to care for young children [215]. Length of school closures have a significant economic and social costs that can have negative effects on key workers who will need to make significant and sometimes costly arrangements for child care while schools are closed. This can also affect the availability of frontline health and social care staff. Evidence from the UK shows that the main cost of school closure is associated with absenteeism of frontline working parents who will have to stay home to take care of their children because of the huge childcare cost they may have to pay (between $£ 0.2$ billion and $£ 1.2$ billion per week, with the total cost of a 12-week school closure in the range of $0 \cdot 2-1.0 \%$ of GDP). About $16 \%$ of the workforce is likely to be the main carer for dependent children and likely to be absent from work if schools are closed [216]. Lesson learnt so far with the Covid-19 pandemic seems to advocate for the development of online virtual capacity for school children to continue to learn and do assignments from homes to limit the effect of disruptions to learning and 
development of school children. National government must realize that households with a low income or from minority groups are particularly exposed to serious financial problems if schools are closed for a prolonged period. There is therefore need for government to provide palliatives to help low income individuals including those from minority groups [217].

\section{Provision of Necessities and help during Pandemics}

Pandemics are often associated with reduced access to public places, such as markets, stores, and pharmacies which may be closed or subject to limited access [218]. It is vital that government realize that in the midst of a pandemic, people will need to procure food, medicine, and other necessities [219]. In the midst of the current Covid-19 pandemic, it has become clear that total shut down of mass transportation (bus, coach, train, tram, flights and maritime) may prevent people particularly those without other source of mobility from being able to move from place to place to obtain essential supplies. National government must put backup plans in place knowing fully well that the freight, bulk goods, and energy transportation network comprise the maritime, rail, air, and trucking industries. It relies on small numbers of specialized workers who cannot be rapidly replaced if lost due to death, illness, or voluntary absenteeism. Since transportation networks link economies, provide critical infrastructures with working material, and supply citizens with necessary commodities, disrupted transportation systems can lead to cascading failures in social and economic systems. There is need for nations, states, the transportation industry, labour unions, businesses and other stakeholders to plan, resource, exercise, conduct a transportation health assurance and security campaign to manage the current Covid-19 and future pandemics [220]. Evidence has shown that people with limited resources are unable to stockpile supplies before lockdown occur. There is need for government to provide citizens with limited resources financial help to enable them meet their basic needs during the pandemic [221]. Government must have a strategic plan to provide food, medicine, and other necessities to its citizens during a pandemic. There should be advance warning of the pandemic and intended lockdown as well as advice on the need and quantity food, medicine, and other supplies to stockpile. National government must guarantee that the networks for the distribution of necessary provisions to supermarkets, pharmacies remain open to ensure that supplies continue to run unhindered [222]. There is also need for the provision of facilities for the safe removal of bodies of person who unfortunately die in their homes as well as building more medical transport and mortuary capacity and services [223].

\section{International Travel and Border Control Measures}

The current COVID-19 outbreak is the third novel coronavirus to emerge in this 21 st century, after the 2003 SARS and the 2013 Middle East respiratory syndrome (MERS) [224]. In December 2019, a novel coronavirus outbreak, COVID-19, caused by the severe acute respiratory syndrome coronavirus 2 (SARS-CoV-2), emerged in Wuhan, Hubei province in China presenting as a cluster of cases exhibiting pneumonia-like symptoms; fever, breathlessness and short of breath [225]. A significant number of people worldwide undertake air travel annually. There are concerns that surrounding cabin air quality can 
facilitate the potential transmission of respiratory infections such as Covid-19 [226]. Globally, increasing ease, affordability, availability of air travel and mobility of people has become major vehicles for the transmission of airborne diseases transmission during commercial air travel are an important public health issue [227]. Respiratory tract infections (via droplet spread and by the airborne route) have been shown to be the second commonest cause of post travel illness after gastrointestinal infections [228-230]. It is becoming glaringly clear the importance of prompt implementation of border measures, including outright travel ban to symptom screening of passengers travelling from countries particularly those experiencing a significant spread of a respiratory pandemic like Covid-19 that is transmitted by aerosols [231]. Within a few weeks following the outbreak of Covid-19 pandemic, SARSCoV-2 has spread to 24 other countries around the world, including the United States, Canada, the United Kingdom, France, Australia, and Japan [232]. As of February 21, 2020, more than 76,000 cases have been confirmed globally, of which $1.8 \%$ have been reported outside mainland China [233]. With the rapid global spread of the SARS-CoV-2 cases particularly out of China, many countries started implementing border measures, including outright travel ban, travel restrictions and symptom screening of passengers travelling from China [234]. In response to its global spread, many countries implemented airport screening. While these measures seem to have been effective in slowing down the rate of exportation from mainland China to other countries, it does not seem to have been sufficient in containing the global spread of COVID-19. Several authors have noted that these measures may not have been as effective as expected because of the initial delay in their implementation; the long incubation period associated with the SARS-CoV-2 resulting in infected international travellers arriving during the asymptomatic incubation phase of the disease, poor contact tracing and the non-compliance to quarantine and isolation measures [235-237]. Transmission modelling project to determine the impact of travel limitations on the national and international spread of the Covid-19 indicate that sustained $90 \%$ travel restrictions to and from mainland China only modestly affect the epidemic trajectory unless combined with a $50 \%$ or higher reduction of transmission in the community [238]. Report from China indicated that the Wuhan shutdown was associated with the delayed arrival of COVID-19 in other Chinese cities by 2.91 days. Cities that implemented control measures pre-emptively reported fewer cases on average (13.0) in the first week of their outbreaks compared with cities that started control later (20.6). Also, suspension of intracity public transport, closing entertainment venues, and banning public gatherings was associated with reductions in case incidence [239]. At 2am on the 23 January 2020, the Chinese authorities issued a notice informing residents of Wuhan that from $10 \mathrm{am}$, all public transport, including buses, railways, flights, and ferry services would be suspended. This notice came in two days before the Chinese New Year, an important festival that is associated with millions of Chinese traveling across the country [240]. The notice caused an exodus of an estimated 300,000 people (potentially infected with the virus) from Wuhan by train alone before the $10 \mathrm{am}$ lockdown. By the afternoon of 23 January, when the authorities began shutting down some of the major highways leaving Wuhan, it was too late to prevent the spread of the virus to 262 other Chinese cities and by extension other parts of the world [241-242]. Also, there seems to have been a delay in implementation of travel ban, restriction and screening in most nations to limit the importation of SARS-CoV-2 from mainland China to other countries in the early days of the epidemic. At the early stages of the epidemic, reduction in the rate of exportation could have significantly delayed the importation of cases into cities unaffected by the 
COVID-19 outbreak. However, buying time to coordinate an appropriate public health response may have triggered the rapid spread of the virus across the globe [243]. This was a missed opportunity that nations including those that are not currently experiencing a significant spread will need to learn from to mitigate the spread of this current and future pandemics.

\section{The need for the diversification of the global medical supply}

The outbreak of Coronavirus Disease 2019 (COVID-19), first in Wuhan China, and then globally, including in the Western nations like United Kingdom, France, Germany, Italy, Spain and the United States has drawn attention to the ways in which the economies in the West is vulnerable and depends on manufacturing and supply chains for medical supplies based in China. The Coronavirus pandemic and its proliferation globally is clearly a key threat and challenge to vital health supplies required for the effective and safe management of the Covid-19 pandemic. With the rapid spread of the Covid-19 in China and the associated lockdown, the production of these vital supplies plummeted. The primary objective of the Chinese government became to prioritize meeting her own health supply needs before those of other nations. In early February 2020, the Chinese government nationalized control of the production and distribution of medical supplies in China. This policy led to shortages of critical medical supplies to the West. There has also been unsubstantiated report that in the peak of the COVID-19 outbreak, the Chinese government was only selectively releasing some medical supplies for overseas delivery to countries perceived as ally in ways that seek to improve China's global image. While China was battling with the spread of the Covid-19 in the mainland, the virus was also spreading in countries in the West including notably Italy, Spain, France, UK, Germany, other countries in Europe and the US. Concerned about shortages and its ability to contain the COVID-19, the Chinese government nationalized and transferred authority over the production and distribution of medical supplies from the Ministry of Information Industry and Technology (MIIT) to the National Development and Reform Commission (NDRC), China's powerful central economic planning ministry. NDRC commandeered medical manufacturing and logistics down to the factory level and has been directing the production and distribution of all medical-related production lines in China, for domestic use. With this implementation, it became glaring that vital medical suppliers including ventilators, PPE (face mask, hand gloves, aprons, goggles, visor and others), laboratory consumables, testing kits and viral transport medium and swab stick for sample collection needed to deal with the crisis was in short supply. The West having outsourced their medical supplies and by extension their wellbeing to China, became at the mercy of the Chinese to meet the supply chain requirement for these vital health supplies. The over dependence and reliance on China for global medical supplies has implications on public health. There has also been report of production of products of suboptimal quality and standards which led to some European countries imposing export restraints on Chinese health supplies. In the light of reported cases of shortages in vital medical supplies including personal protective equipment (PPE) and pharmaceuticals in many Western countries, there may be need for a strategic plan to reduce the dependence of the West for vital medical supplies from China. There are a number of options potentially on the table to change this unhealthy tide. Firstly, Western nations can encourage company at home in the West to 
produce these vital supplies by providing them tax breaks to facilitate affordable productions. Another option is to develop manufacturing capacity and plants in developing economies like Mexico, Brazil, India, Pakistan and Africa to produce the supplies at affordable rate and reduce the over dependence on Chinese exports [244]. There is need for Western countries to consider the potential longer-term advantages and disadvantages of diversifying the vital health supplies by on-shoring of certain capabilities. There may be need for these countries to consider potential collaboration to increase local production of these supplies (particularly essential medicines that are core to national health security and national security) to protect national supplies and those of developing economies that could be hit particularly hard by COVID-19 and may be at the mercy of the Chinese. There is the urgent need for Western Countries and the United States to seek to diversify away from China the production of these vital health supplies because of vulnerabilities that have become apparent with the Covid-19 pandemic [244].

\section{The need for Collaborative efforts in the development of effective treatment for Covid-19}

The Coronavirus disease (COVID-19) first discovered in Wuhan China in December 2019 is posing a global challenge, particularly because of the rapid spread across the globe and the absence of definitive treatment or vaccine [245-246]. To date, over 81,000 cases have been confirmed, with over 2700 deaths. The mortality appears to be around 2\%; early published data indicate $25.9 \%$ with SARS-CoV-2 pneumonia required ICU admission and $20.1 \%$ developed acute respiratory distress syndrome. There is presently no vaccine or specific antiviral drug regime used to treat critically ill patients. The management of patients currently is essentially supportive and includes oxygenation, ventilation, and fluid management. Combination treatment of low-dose systematic corticosteroids and anti-virals and atomization inhalation of interferon have been encouraged as part of critical COVID-19 management [247]. Coronavirus 2 (SARS-CoV-2) is spreading rapidly across many nations with increasing numbers of patients with acute respiratory failure and associated high mortality rates of $40-65 \%$ for those requiring mechanical ventilation [248]. Critical care physicians are longing for therapeutic agents they can combine with supportive treatments to reverse hypoxaemia, provide adequate organ support, decrease viral load and thus limit disease severity. In the absence of definitive management protocols, many treatment regimens are being explored around the world for the treatment of COVID-19 including several antiviral agents and an antimalarial drug. Some in-vitro studies have shown that chloroquine and hydroxychloroquine can both inhibit SARS-CoV-2 transmission [249-251] through the alkalinisation of the intracellular phagolysosome, which prevents virion fusion and uncoating and by extension the spread of the virus. Reports from clinical studies conducted in China suggest that chloroquine use might be associated with reduced fever, increased resolution of lung lesions on CT, and delayed disease progression [252]. Similarly, results of two French studies suggested that hydroxychloroquine could reduce the viral load in patients with COVID-19 particularly if combined with azithromycin. Early results from clinical studies conducted in China suggest that chloroquine use might have been associated with reduced fever, increased resolution of lung lesions on CT, and delayed disease progression. Results of two French studies suggested that hydroxychloroquine could reduce the viral load in patients 
with COVID-19-in particular, if combined with azithromycin [253-254]. Although Hydroxychloroquine has been used for years in African countries for the safe treatment of malaria infection, there is however the need for its evidenced based used in management of Covid-19 [255]. There has also been a reported approach for the use of serum of recovered patients for the management of patients with Covid-19 [256]. Trials are underway to study its effectiveness. There is need for a global collaborative effort and clinical trials aimed at identifying effective treatment for Covid-19. Vaccination is the most widely available and used form of disease control. It is most effective at the start of an epidemic [257]. The major challenge however is that several months would be required to produce a vaccine against a viral strain [258]. Although vaccine for general use takes time to develop, however through collaborative efforts the process can be fast tracked particularly because a vaccine remain the ultimate instrument needed to control this worldwide pandemic and reduce the associated mortality rate [259]. There is need for collaborative efforts among scientists, physicians, funders, national governments and manufacturers coordinated by the

\section{The Quest for a vaccine}

It's been 17 years since the severe acute respiratory syndrome (SARS) caused by a coronavirus appeared in China. One of the biggest changes since SARS 2003 outbreak has been understanding the virus and developing diagnostic tests or treatments. There are many puzzles associated with the current SARS-COV-2 (Covid-19) virus. One of them is why the current coronavirus has so far been merciless and has brought the entire world to almost a standstill unlike the previous deadly coronavirus, SARS virus. The second puzzle is that the 2003 SARS outbreak spread within months to more than two dozen countries in Europe, North America, South America, and Asia affecting over 8000 people and causing 800 deaths before being contained not requiring a vaccine unlike the current Covid-19 virus that has in 5 months so far caused the death of 284,022 people [261]. The third puzzle is that the Covid-19 causes an illness with symptoms such as fever, cough, and shortness of breath has already several times surpassed SARS and it is continuing to rage. As of the 10th of May 2020, over 4,195,159 cases of COVID-19 have been reported worldwide, with 284,022 deaths. There are currently no specific antiviral treatment or vaccine for it. There are several questions that have arising from the Covid-19 pandemic; what can we learn from the SARS 2003 outbreak to enable us better manage the current Covid-19 pandemic [262]. Secondly, why do we urgently need a vaccine now to stop the spread of the current SARS-COV-2 when we never need one to contain its cousin SARS-COV-1. SARS-COV-2 is a cousin of the SARS-CoV-1 (cause of SAR 2003 outbreak) family of coronaviruses. Like the Covid-19 outbreak SARS (severe acute respiratory syndrome) was first detected in Guangdong province, China in November 2002 associated with an unusual pneumonia like illness. Report has shown that the RNA genomes of both viruses are about $80 \%$ identical. It seems that there are a lot of things we are yet to understand about the SARS-COV-2 that may help us better manage this pandemic. It is mysterious that SARS in 2003 was highly lethal killing about one in 10 infected people but fizzled away quickly without a vaccine. There are some similarities and differences associated with both viruses. SARS-CoV-1 and SARS-CoV-2 are focused on the lungs. SARS-CoV-1 is more aggressive and lethal than SARS-CoV-2. SARS-CoV-2 spreads faster, sometimes by asymptomatic infected persons. With SARS-CoV-1, contact tracing is 
easier as symptoms usually appear in two to three days unlike the SARS-CoV-2 which takes 7-14 days. Scientist worldwide has so far been more proactive with Covid-19 compared to the SARS 2003 outbreak. Chinese scientists as early as January 2020 had sequenced the virus a month after the outbreak was reported in December 2019. An information the Chinese has team playingly shared with scientists around the world unlike the SARS -COV-1 outbreak where it took scientists about 5 months to identify the virus. The genetic information about the virus is key to helping scientists develop diagnostic tests, treatments and vaccines. Prompt and proactive information sharing following an outbreak plays a key role in identifying the virus and significantly helps public health officials to contain and mitigate the effect of a pandemic. Management of a pandemic rely on a number of things; development of antiviral agents and vaccine development. Vaccine production is complex and time consuming. There are several hurdles a new vaccine must overcome in order to reduce morbidity and mortality [263-264]. It is projected to take about 12 to 18 months before a Covid-19 vaccine is ready for widespread use in people. There was an inactivated whole virus vaccine developed against SARS-CoV-1. The vaccine was tested in animal model (ferrets, non-human primates and mice). Report indicated that vaccines showed protective immunity. However, it was associated with complications of an immune disease in the animals. Luckily the virus fizzled into thin air and human studies were not carried out. Several factors were noted to have played a role in bringing an end to SARS-CoV-1; the coming of the warm summer weather and the strict isolation of infected persons as well as the tracing and quarantining of all contacts of infected persons. Scientist seems to be trying to obviate the challenge associated with the SARS-CoV-1 and tend to be using portions of the inactivated viral RNA rather than using the whole virus. Like the SARS-CoV-1 vaccines, some Phase II clinical trials have reported disappointing results, possibly because the vaccine recipients or target population have a natural tendency for impaired immune responsiveness or develop complications [264]. Cost is also a major challenge associated with vaccine development. Common estimates for research and development $(\mathrm{R} \& \mathrm{D})$ for a single vaccine are often based on development costs for new drugs and fall into the \$1-2 billion range [265]. Many different options are being tried all over the world at this very moment with the hope of getting a safe and effective vaccine for global use. The world eagerly wait for a vaccine against SARS-COV-2 to be quickly produced and delivered in mass quantities. However, two questions ensue particularly from a legal point of view; what are the regulatory steps to get there and what needs to be done for the vaccine to be administered legally? [266]. The various steps, protocols and clinical trials leading to a vaccine production is usually a long, laborious and expensive process due to the in-depth testing and approval protocols involved [267]. Although the need for flexibility and pragmatism cannot be over emphasized with developing a vaccine against SARS-COV-2. The first priority however is that safety of trial participants is not compromised in any way. For a vaccine to be acceptable it must pass safety tests and demonstrate that it works in animals, generates an immune response, is safe and efficacious in phase 1,2 and 3 clinical trials in human and are not associated with potential side effects and adverse events or that the potential benefits far outweigh the side effects. There is a more rapid way to develop a vaccine against SARS-COV-2 by testing the efficacy of the vaccine by the deliberate exposure of vaccinated volunteers with the virus rather than waiting for them to encounter the virus naturally through community exposure. There are however 
serious associated ethical issues because of the potential risk of death. Many governments around the world are looking for paths out of restrictive physical distancing measures imposed to control the spread of SARS-CoV-2 [268]. With a potential vaccine against coronavirus disease 2019 (COVID-19) many months away, one proposal that some governments including Chile, Germany, Italy, the UK, and the USA [269] is considering is the potential to use the immunity passports (digital or physical documents) that certify an individual has been infected and is purportedly immune to SARS-CoV-2. Individuals in possession of an immunity passport could be exempt from physical restrictions and could return to work, school, and daily life. However, immunity passports will pose considerable scientific, practical, equitable, and legal challenges [271].

\section{Provision of Isolation and Quarantine Facilities}

Isolation and quarantine are two of the readily available and effective disease-control methods in existence that has been very effective so far in the prevention of the spread of Covid-19. Quarantine is a term used to describe the restriction of the activities of asymptomatic persons who have been exposed to a person infected with a communicable disease for a period of time covering the incubation period of the infective agent. The aim is to prevent disease transmission [272] as well as allow the person to develop symptoms of the disease and be tested. Isolation on the other hand is the separation of an infective individual during a period when they are infectious and capable of spreading the disease allowing them to be effectively treated [273]. People can potentially be quarantined or be in isolation in their own homes or purpose built or designated quarantine or isolation centres. Quarantine and isolation can be self or imposed by the health authorities in the interest of the public health. It has ethical and human right implications. It is often associated with the deprivation of a person's liberty in name of public health and often causes tension between the interests of society in protecting the health of its citizens and the fundamental human rights (civil liberties) of individuals, such as privacy, non-discrimination, freedom of movement, and freedom from arbitrary detention. Previous report indicates that coercive public health powers such as quarantine and isolation can be legitimately justified if the public health interests of society are carefully balanced against the freedom of the individual [274]. To pass the balancing test, the potential benefits to the public should outweigh the burdens, discomfort or harms that quarantine may place on individuals. In the light of the current Covid-19 pandemic, it is vital that all nations comply fully with the Siracusa principles (internationally agreed-upon legal principles that establish the conditions under which restrictions on civil liberties are justified) [275]. The general expectations of the principles include that restrictions must be legal, (federal, state, local, municipal, foreign, international, multinational, or other administrative order, constitution, law, ordinance, principle of common law, regulation, statute, or treaty), proportionate (severity of the restriction should fit the seriousness of the pandemic), necessary (there is justification) and accomplished by the least restrictive means that are reasonably possible. Coercive quarantine and isolation are often used when a disease is known through extensive scientific study and evidence to be contagious and should be limited to persons who are infected or exposed to the disease. Public health authorities should carry out public enlightenment campaign and honestly and 
transparently disclose the public health reasons why the restriction is put in place to facilitate public acceptance and participation [276]. There is need for national government to invest in developing safe, humane, conducive, comfortable and optimally equipped quarantine and isolation centres with all the necessary equipment and PPE are available to enable healthcare workers manage and monitor infected and exposed individuals. There is also the need for adequate pandemic preparedness to facilitate the optimum staffing of these centres with appropriately trained and motivated healthcare workers. The Coronavirus pandemic could inflict long-lasting anxiety, loneliness, and depression emotional trauma on an unprecedented global scale [277-279]. Confinement by way of isolation or quarantine creates a significant psychological trauma and hardships on the affected individuals who are often denied access to family and loved ones. There is need for development of capacity to offer counselling for these individuals. A previous report indicated that about 30 percent of individuals quarantined during the SARS pandemic, suffered from posttraumatic stress disorder and depression [280-281].

\section{Need for the Implementation of Evidenced -Based Best Practices and life style changes}

Pandemics can cause sudden, widespread morbidity and mortality as well as social, political, and economic disruption. There is need for the implementation of evidenced -based best practices learnt from dealing with previous pandemics and the ongoing Covid-19 pandemic [282]. Pandemics are large-scale outbreaks of infectious disease that can greatly increase morbidity and mortality over a wide geographic area and cause significant economic, social, and political disruption [283]. Several knowledge gaps have been identified from dealing with past pandemics that may need to be taken into consideration to facilitate the effective management of the ongoing Covid-19 pandemic; costs specifically associated with pandemic preparedness and response efforts are poorly tracked; there is no consistent methodology for estimating the social economic impacts of pandemics; data regarding the impacts of pandemics and the cost-benefits analysis are poorly tracked. There are peculiarities associated with pandemics; morbidity and mortality tend to be disproportionately higher in low- and moderate-income countries (LMICs); is associated with significant economic or fiscal shocks requiring short-term, medium- and long-term stimulus plan and packages to foster economic growth and associated with people having to make changes to their behavior to mitigate the spread of the virus. There are a number of increased awareness lifestyle-related changes we will need to make to mitigate against the spread of this and any future pandemics. Having quality sleep (at least 8 hours a day), eating healthy food and exercise can play a major role in controlling and preventing the virus spreading [284-285]. Avoiding contact with symptomatic persons, practice respiratory hygiene by covering our mouth and nose with our bent elbow or tissue when we cough or sneeze and then disposing the used tissue safely since droplets spread virus. Covering sneeze or cough with a tissue and discarding the contaminated tissue in a contained trash, avoid unnecessary travels to high risk areas, washing of hands with soap and water for at least 20 seconds or with a disinfectant that contains at least $60 \%$ alcohol if soap and water are unavailable, avoiding hand contact with facial components, provision of water and sanitation systems, increasing situational public health enlightenment on reducing 
the transmission, treatment and safe caring for affected loved ones; avoid touching eyes, nose and mouth because hands touch many surfaces and can pick up viruses from contaminated surfaces. Once contaminated, the hands can become vehicles for transfer of the virus to the eyes, nose or mouth; staying at home and seeking care early by calling healthcare providers and following their advice and that of local health authorities if having Covid-19 related symptoms of fever $(\geq 37.80 \mathrm{C})$, cough and SOB or difficulty breathing loss of taste and smell (Anosmia) avoiding visits to medical facilities unless in emergency of if case becomes worse to allow health workers and facilities operate more effectively and not being overwhelmed by COVID-19 and staying informed on the latest developments about COVID-19 from reliable sources and following useful advice from healthcare providers, public health authority and employers on how to protect yourself and others from COVID-19. These mitigation steps will need to be implemented until it becomes a culture around the world to limit the spread of the disease and to enable us effectively deal with the ongoing Covid-19 and any future pandemics.

\section{Economic and Social Realities of Covid-19 Pandemics}

In the light of this current Covid-19 pandemic there is need for the provision of increased official development assistance (ODA) to affected and vulnerable countries, including direct budgetary support. Lower Middle-Income Countries (LMICs) are likely to face larger budget shortfalls, potentially leading to weakened public health response or cuts in other government spending. Stockpiling of vaccines, medicines (including antibiotics and antivirals), and equipment (such as masks, gowns, and ventilators) also can be useful for building local surge capacity [286]. During a pandemic, health systems can rely and access stockpiles more quickly than it is feasible to order from external suppliers or boost local production. However, there are basic realities and four important things to consider with stockpiling; it has significant cost implication particularly in developing countries where money tied down to maintain stockpiles could be diverted to building critical infrastructure [287]. Also, it is difficult to maintain a stockpile of certain items such as vaccines since the strain responsible for future pandemic may differ from the virus to which the stockpiled vaccine is targeted. This can result in colossal loss and may not achieve the desired aim; the optimal quantity is difficult to determine and there is risk of outdating. This can however be prevented by rotating the stock on a regular basis and there is need to have a process in place that allow the stockpile to be distributed months to outdating to allow for replenishment. Preparing for a pandemic has a significant cost implication. The discovery and detection of the majority of zoonotic viruses could cost as much as much as US\$1.6 billion [276]. The Global Virome Project, aimed at characterizing more than 99 percent of the world's viruses, is estimated to cost a whooping US\$3.4 billion over 10 years [288]. The cost of developing technology platforms and producing facilities for vaccine production to outbreaks of known or unknown pathogens can cost an excess of US $\$ 1$ billion over five years period [288]. The novel coronavirus that emerged in Wuhan, China, in December 2019 has leaped across borders, sending ripples around an interdependent and highly mobile global population. Apart from the tragic and colossal loss of life due to the COVID-19 coronavirus epidemic, the economic uncertainty it has sparked will likely cost the global economy $\$ 1$ trillion in 2020 [289]. 
Available evidence now indicates that the COVID-19 pandemic constitutes an unprecedented challenge with very severe socio-economic implications for both developed and developing economies. A global concerted, coordinated and comprehensive strategy (short, medium and long-term) is required to manage the health, economic and social challenges caused by the virus [290]. To counter these fears, "governments across the globe will need to spend to prevent the economic meltdown or recession. Several economies across the globe are particularly fragile. Developing countries who were already heavily indebted particularly exporters of commodity goods are likely going to be the worst hit as a result of poor returns due to weaker export and returns [291]. According to the World Health Organization (WHO) head, Tedros Adhanom Ghebreyesus the treat of SARS-CoV-2, the virus that causes the disease COVID-19 is huge and very real. The world seems to be at the mercy of this virus that has so far claimed 340,075 lives as at the 23rd of May, 2020. While China seems to have managed to contain the virus, many developed economies (Europe and USA) and other developing countries continue to grapple with severe outbreak with significant toll on lives. There has been change associated with the supply of personal protective equipment (PPE), ventilators, medicines and other essential equipment needed to effectively manage infected patients. As the virus continues to spread across several economies across the globe, its epidemiological trajectory is leaving behind a trail of health, social, economic challenges. It is projected that that $20 \%$ to $80 \%$ of the global population are likely to be infected at the end of this pandemic. In the absence of a vaccine and scientifically proven medicines for the management of this virus, preventive measures (lockdown, self-isolation of symptomatic individuals, quarantine of contacts of infected persons, effective hand hygiene practicing, social distancing, policy for staff to work from home if feasible, universal wearing of face mask, border closures and evidenced based school and business closure) remains measures that affected countries may need to continue to implement in a bid to containing or reducing the rate of infection and to flatten the peak. The economic reality of this pandemic is bleak. It is likely to cripple even the most robust economies, threatening national and global growth and may result in significant economic meltdown plunging the world into a deep recession. Several sectors (services travel, hospitality, tourism, aviation) have been worst hit resulting in significant job loses and many are now resulting to claiming unemployment benefits particularly in the West. The reality is graver in developing countries particularly in Africa where there is failure in stewardship by government to provide some respite or relief for citizens whose livelihoods has been affected by this pandemic. Prediction from the Organization for Economic Co-operation and Development (OECD) now indicates that many countries may still be dealing with the economic effect of the COVID-19 pandemic for many years to come [292]. The true direct cost of this pandemic (human and material) is huge and include; direct costs (testing, contact tracing, isolation, hospital treatment, vaccine and therapeutics development, wages for healthcare staffs, out of pocket cost particularly in developing countries); indirect costs (costs associated with either being sick or the economic impact of measures adopted such as self-isolation and quarantine to avoid becoming infected or potentially infecting other; productivity losses arising from workers being absent from work due to illness and mortality); production and supply shocks (due to reduced production as a result of government-imposed shutdown in factories in most industrial nations like China, transportation restrictions, challenge of raw materials sourcing due to stockouts); 
education (huge economic and social disruption associated with school closures); other health issues (inability of persons with other health conditions require elective surgeries, mental health disorders to get care from health services overwhelmed by caring for COVID-19 patients); capital flows challenges (lockdowns and movement restrictions on movement have a significant impact on trade, commerce and investment as a result of reduction in demand for goods and services); travel and tourism (lockdowns, travel restrictions has significantly affected the travel and tourism industry with associated huge job losses particularly in countries where travel and tourism contributes significantly to national GDP); personal consumption (prolonged economic disruption resulting from Covid-19 related lockdowns and movement restrictions could lead to lower consumer and business confidence and decreased consumer spending affecting jobs in the retailing sectors); financial market losses (effect of COVID-19 related disruption to shipments and production resulting in global stock markets plunge and fall in oil prices). The impact of COVID-19 is expected to be substantially higher given its extended reach. The Organisation for Economic Co-operation and Development (OECD) and the International Monetary Fund (IMF) have warned that the economic shock from the virus is already larger than the global financial crisis of 2008. There is need for the prompt and proactive delivery of massive fiscal stimulus packages and economic relief plans to help minimize the likelihood of an economic recession, economists have estimated that the global economy will shrink to between $0.5 \%$ to $1.75 \%$ through 2020 with economic losses of USD $1-2.7$ trillion. The UN has also projected that foreign direct investment flows could fall between $5 \%$ and $15 \%$ plunging low-income countries into further disadvantage [293]. COVID-19 has changed our lives in ways that we never imagined. In just a few short months this year 2020, the impact of this devastating virus has shut schools, offices, stores and factories, airlines grounded, national economies have been battered, borders are closed, many are quarantined, there is massive job losses and over 350,000 are dead. Governments around the globe need to act quickly and proactively to design some of the biggest economic stimulus plan ever seen in peacetime in response to the COVD-19 pandemic [294]. In times of pandemic, fiscal policy is key to save lives and protect people. Governments have to do whatever it takes. But they must make sure to keep the receipts. Other nations are encouraged to learn from countries like Germany, UK and Spain that have already taken bailout measures in excess of 20 percent, 15 percent, 8 percent of GDP [295]. Also, the \$2 trillion US stimulus package [295] which is more than double the amount of the Obama administration equivalent bailout package of 2009 is worthy of emulation [296]. The Minister of Economy, Paulo Guedes, announced in March 26th that the economic stimulus package, closed by the Ministry of Economy, Public Banks and the Central Bank will be US\$150 billion (R $\$ 750$ billion), to face the economic impacts of COVID-19 in Brazil [297]. China is preparing stimulus measures to give the economy a blow as it recovers from the COVID-19 coronavirus. The government's quarantine and pandemic management measures over the past three months have brought China's economy to a standstill. China is currently working her way to normalcy while the outbreak is accelerating in the rest of the world resulting in plummeting of overseas demand for Chinese exports. This is likely to truncate the economic growth in China to as low as 2.3 percent than originally projected [298]. Economies around the globe are encouraged to do all it takes to avoid permanent scarring by providing targeted support to viable businesses in a bit to limiting layoffs and bankruptcies. There is also the 
need for significant investment to support households to ensure access to basic goods, services and to a decent standard of living. In the light of these challenges governments around the globe should reinforce principles of good governance, transparency, proper documentation and open accountability. Many countries are facing unprecedented challenges from COVID-19. The strain on many governments across the globe is extreme and the impact on people all over the world continues to grow. There is also need for community support by existing local charities and community groups to help the vulnerable in society (elderly, people with mental health issues, people with a disability or long-term health condition such as cancer, diabetes and chronic lung disease and people who are self-isolating and needing material help) [299-301].

\section{Conclusion}

The Coronavirus disease (COVID-19) first discovered in Wuhan China in December 2019 is posing a international challenge, particularly because of the rapid spread across the globe and the absence of definitive treatment or vaccine. The recommendation moving forwards include the development of a strong focus on comprehensive testing and surveillance strategies (including isolation and treatment of those infected, contact tracing and quarantining of close contacts of those infected), community measures (including physical distancing and wearing of non-medical face masks in public places), protection and strengthening of healthcare systems, provision of balanced accurate and transparent scientific -based information sharing, meticulous implementation of hand hygiene (hand washing and use of alcohol based hand sanitizers) and avoiding touching the face, nose, eyes and mouth, use of, global collaboration and information sharing, provision of social and economic assistance to the affected and vulnerable in communities, significant investment into national economies, provision of appropriate and adequate personal protective equipment, provision of an enabling environment that front line staff need to carry out their life saving responsibilities, the promotion of mental wellbeing among people living under physical distancing isolation measures and doubling effort at developing a vaccine against Covid-19.

\section{References}

Setiawan, Adib Rifqi. (2017, February 24). Penerapan Pendekatan Saintifik untuk Melatihkan Literasi Saintifik dalam Domain Kompetensi pada Topik Gerak Lurus di Sekolah Menengah Pertama. Undergraduate Thesis. Bandung: Universitas Pendidikan Indonesia. URL: http://repository.upi.edu/29074/

Setiawan, Adib Rifqi. (2020, April 21). Lembar Kegiatan Literasi Saintifik untuk Pembelajaran Jarak Jauh Topik Penyakit Coronavirus 2019 (COVID-19). Edukatif: Jurnal Ilmu Pendidikan, 02(01): 28-37. DOI: https://doi.org/10.31004/edukatif.v2i1.80

Setiawan, Adib Rifqi. (2020, March 01). Pendidikan Literasi Finansial Melalui Pembelajaran Fiqh Mu'āmalāt Berbasis Kitab Kuning. Nazhruna: Jurnal Pendidikan Islam, 03(01): 138159. DOI: https://dx.doi.org/10.31538/nzh.v3i1.522

Setiawan, Adib Rifqi. (2020, January 24). Pembelajaran Tematik Berorientasi Literasi Saintifik. Jurnal Basicedu: Journal of Elementary Education, 04(01): 71-80. URL: https://jbasic.org/index.php/basicedu/article/view/298 
Setiawan, Adib Rifqi. (2019, December 30). Instrumen Penilaian Pembelajaran Fiqh Mu'āmalāt Berorientasi Literasi Finansial. Eklektik: Jurnal Pendidikan Ekonomi dan Kewirausahaan, 02(02): 258-272. DOI: http://dx.doi.org/10.24014/ekl.v2i2.8117

Setiawan, Adib Rifqi. (2019, December 20). Literasi Saintifik Berdasarkan Kecerdasan Majemuk dan Motivasi Belajar. Media Penelitian Pendidikan: Jurnal Penelitian dalam Bidang Pendidikan dan Pengajaran, 13(02): 126-137. DOI: http://dx.doi.org/10.26877/mpp.v13i2.4913

Setiawan, Adib Rifqi; Puspaningrum, Mita; \& Umam, Khoirul. (2019, December 06). Pembelajaran Fiqh Mu'āmalāt Berorientasi Literasi Finansial. Tarbawy: Indonesian Journal of Islamic Education, 06(02): 187-102. URL: https://ejournal.upi.edu/index.php/tarbawy/article/view/20887

Setiawan, Adib Rifqi. (2019, October 02). Efektivitas Pembelajaran Biologi Berorientasi Literasi Saintifik. Thabiea : Journal of Natural Science Teaching, 02 (02): 83-94. DOI: http://dx.doi.org/10.21043/thabiea.v2i2.5345

Setiawan, Adib Rifqi. (2019, September 30). Instrumen Penilaian untuk Pembelajaran Ekologi Berorientasi Literasi Saintifik. Assimilation: Indonesian Journal of Biology Education, 02(02): 42-46. DOI: https://dx.doi.org/10.17509/aijbe.v2i2.19250

Setiawan, Adib Rifqi; Mufassaroh, Arij Zulfi. (2019, June 28). Menyusun Soal Literasi Saintifik untuk Pembelajaran Biologi Topik Plantae dan Animalia. BIOSFER: Jurnal Biologi dan Pendidikan Biologi, 04(01): 33-40. URL: http://dx.doi.org/10.23969/biosfer.v4i1.1484

Setiawan, Adib Rifqi. (2019, June 26). Peningkatan Literasi Saintifik melalui Pembelajaran Biologi Menggunakan Pendekatan Saintifik. Journal of Biology Education, 02(01): 223-235. URL: http://journal.stainkudus.ac.id/index.php/jbe/article/view/5278

Setiawan, Adib Rifqi; Utari, Setiya; Nugraha, Muhamad Gina. (2017, September 22). Mengonstruksi Rancangan Soal Domain Kompetensi Literasi Saintifik Siswa SMP Kelas VIII pada Topik Gerak Lurus. Wahana Pendidikan Fisika, 02(02): 44-48. URL: https://ejournal.upi.edu/index.php/WPF/article/view/8277/0

Setiawan, Adib Rifqi. (2020, April 20). Menyusun Instrumen Penilaian untuk Pembelajaran Ekologi Berorientasi Literasi Saintifik. Prosiding Seminar Nasional dan Workshop BiologiIPA dan Pembelajaran Ke-4 (SnoWBel IV): 241-9. ISBN : 978-602-470-170-3 \& eISBN : 978-602-470-171-0.

Setiawan, Adib Rifqi. (2020, February 18). Menyusun Instrumen Penilaian untuk Pembelajaran Topik Lingkungan Berorientasi Literasi Saintifik. Prosiding Seminar Nasional Fisika (SiNaFi) 2019: 15-21. URL:

http://proceedings.upi.edu/index.php/sinafi/article/view/563

Setiawan, Adib Rifqi. (2020, January 17). Penggunaan Mabadi 'Asyroh dalam Pembelajaran Biologi untuk Meningkatkan Motivasi dan Hasil Belajar. Prosiding Seminar Nasional Biologi 2019 Inovasi Penelitian dan Pembelajaran Biologi III (IP2B III): 158-164. URL: http://semnasbiologi.conference.unesa.ac.id/ocs/index.php/semnasbio/IP2BIII/paper/v iewFile/11/21

Setiawan, Adib Rifqi. (2020, January 17). Upaya Meningkatkan Motivasi Belajar dalam Pembelajaran Ilmu Pengetahuan Alam (IPA) Melalui Bacaan Populer. Prosiding Seminar Nasional Biologi 2019 Inovasi Penelitian dan Pembelajaran Biologi III (IP2B III): 154-157. URL:

http://semnasbiologi.conference.unesa.ac.id/ocs/index.php/semnasbio/IP2BIII/paper/v iewFile/5/51

Setiawan, Adib Rifqi. (2020, January 17). Penerapan Pendekatan Saintifik dalam Pembelajaran Biologi sebagai Upaya Melatih Literasi Saintifik. Prosiding Seminar Nasional Biologi 2019 Inovasi Penelitian dan Pembelajaran Biologi III (IP2B III): 140-145. URL: 
http://semnasbiologi.conference.unesa.ac.id/ocs/index.php/semnasbio/IP2BIII/paper/v iewFile/6/19

Setiawan, Adib Rifqi. (2019, October 14). Penyusunan Program Pembelajaran Biologi Berorientasi Literasi Saintifik. Seminar Nasional Sains \& Entrepreneurship VI (SNSE VI): 255-18. URL: http://conference.upgris.ac.id/index.php/snse/article/view/255

Setiawan, Adib Rifqi. (2019, May 07). Penerapan Pendekatan Saintifik untuk Melatih Literasi Saintifik dalam Domain Kompetensi pada Topik Gerak Lurus di Sekolah Menengah Pertama. Prosiding Seminar Nasional Fisika (SiNaFi) 2018: 7-13. URL: http://proceedings.upi.edu/index.php/sinafi/article/view/355

Setiawan, Adib Rifqi. (2019, November 23). Profil Literasi Saintifik Berdasarkan Kecerdasan Majemuk dan Motivasi Belajar. Seminar Nasional Fisika V (SiNaFi 5.0), Universitas Pendidikan Indonesia (UPI). DOI: https://dx.doi.org/10.35542/osf.io/m7n95

Setiawan, Adib Rifqi. (2019, November 23). Menyusun Instrumen Penilaian untuk Pembelajaran Topik Lingkungan Berorientasi Literasi Saintifik. Seminar Nasional Fisika V (SiNaFi 5.0), Universitas Pendidikan Indonesia (UPI). DOI: https://dx.doi.org/10.35542/osf.io/sc6d2

Setiawan, Adib Rifqi. (2019, November 23). Analisis Keabsahan dan Keandalan Science Motivation Questionnaire II (SMQ II) Versi Bahasa Indonesia. Seminar Nasional Fisika V (SiNaFi 5.0), Universitas Pendidikan Indonesia (UPI). DOI: https://doi.org/10.31237/osf.io/6zeph

Setiawan, Adib Rifqi. (2019, October 05). Menyusun Instrumen Penilaian untuk Pembelajaran Ekologi Berorientasi Literasi Saintifik. Seminar Nasional \& Workshop Biologi, IPA, dan Pembelajarannya ke-4 (SnoWBel IV), Universitas Negeri Malang (UM). DOI: https://dx.doi.org/10.13140/RG.2.2.21931.39206

Setiawan, Adib Rifqi. (2019, August 21). Penyusunan Program Pembelajaran Biologi Berorientasi Literasi Saintifik. Seminar Nasional Sains \& Entrepreneurship VI (SNSE VI), Universitas PGRI Semarang (UPGRIS). DOI: https://dx.doi.org/10.13140/RG.2.2.13716.86400

Setiawan, Adib Rifqi. (2019, March 23). Upaya Meningkatkan Motivasi Belajar dalam Pembelajaran Ilmu Pengetahuan Alam (IPA) Melalui Bacaan Populer. Seminar Nasional Biologi 2019 Inovasi Penelitian dan Pembelajaran Biologi III (IP2B III), Universitas Negeri Surabaya (UNESA). DOI: https://dx.doi.org/10.13140/RG.2.2.13087.71847

Setiawan, Adib Rifqi. (2019, March 23). Penerapan Pendekatan Saintifik dalam Pembelajaran Biologi sebagai Upaya Melatih Literasi Saintifik Siswa Sekolah Menengah. Seminar Nasional Biologi 2019 Inovasi Penelitian dan Pembelajaran Biologi III (IP2B III), Universitas Negeri Surabaya (UNESA). DOI: https://dx.doi.org/10.13140/RG.2.2.19798.60484

Setiawan, Adib Rifqi. (2019, March 23). Penggunaan Naḍom Mabādī 'Asyroh dalam Pembelajaran Biologi untuk Meningkatkan Motivasi dan Hasil Belajar. Seminar Nasional Biologi 2019 Inovasi Penelitian dan Pembelajaran Biologi III (IP2B III), Universitas Negeri Surabaya (UNESA). DOI: https://dx.doi.org/10.13140/RG.2.2.33220.37763

Setiawan, Adib Rifqi. (2018, November 24). Penerapan Pendekatan Saintifik untuk Melatih Literasi Saintifik dalam Domain Kompetensi pada Topik Gerak Lurus di Sekolah Menengah Pertama. Seminar Nasional Fisika ke-4 (SiNaFi IV), Universitas Pendidikan Indonesia (UPI). DOI: https://dx.doi.org/10.13140/RG.2.2.23154.04809

Setiawan, Adib Rifqi; Utari, Setiya; Nugraha, Muhamad Gina. (2016, December 17). Mengonstruksi Rancangan Soal Domain Kompetensi Literasi Saintifik Siswa SMP Kelas VIII pada Topik Gerak Lurus. Seminar Nasional Fisika ke-2 (SiNaFi II), Universitas Pendidikan Indonesia (UPI). DOI: https://dx.doi.org/10.13140/RG.2.2.31856.10246/1

Setiawan, Adib Rifqi. (2020, May 12). Introducing the Indonesian Education System. Thesis Commons. DOI: https://doi.org/10.31237/osf.io/ygt5c 
Setiawan, A. R. (2020, May 7). Discovering the Fundamental Problem of Four Methods to Analyze Data. Thesis Commons. DOI: https://doi.org/10.31237/osf.io/h953y

Setiawan, Adib Rifqi. (2020, May 6). Menyibak Makna Karya Fadhilaturrahmi. LIS Scholarship Archive. DOI: https://doi.org/10.31229/osf.io/65y4z

Setiawan, Adib Rifqi. (2020, May 6). Discovering the Meaning of Fadhilaturrahmi's Work. Thesis Commons. DOI: https://doi.org/10.31237/osf.io/krf7z

Feldman, DarHalevy; \& Setiawan, Adib Rifqi. (2020, April 24). Education in Israel. Thesis Commons. DOI: https://doi.org/10.31237/osf.io/62shg

Setiawan, Adib Rifqi. (2020, April 18). Musyāfahah al-Qur'ān Melalui Media Elektronik. Thesis Commons. URL: https://thesiscommons.org/ntjp9/

Setiawan, Adib Rifqi. (2020, April 14). Jalāl al-Dīn 'Abd al-Rohmān ibn Abī Bakr al-Suyūṭ̣̂. SocArXiv. DOI: https://doi.org/10.31235/osf.io/5zf9v

Setiawan, Adib Rifqi. (2020, April 14). Commodification of the Sexuality in Kim Kardashian's Instagram Posts. SocArXiv. DOI: https://doi.org/10.31235/osf.io/kd6au

Velasufah, Whasfi; \& Setiawan, Adib Rifqi. (2020, April 13). Nilai Pesantren Sebagai Dasar Pendidikan Karakter. Thesis Commons. DOI: https://doi.org/10.31237/osf.io/hq6kz

Setiawan, Adib Rifqi. (2020, April 13). Commodification of the Sexuality in Kim Kardashian's Instagram Posts. Thesis Commons. URL: https://thesiscommons.org/mf7nw/

Setiawan, Adib Rifqi. (2020, April 13). مبادئ اللغة العربية. Thesis Commons. DOI: https://doi.org/10.31237/osf.io/2gvjf

Siayah, Syarofis; \& Setiawan, Adib Rifqi. (2020, April 13). A Brief Explanation of Science Education. EdArXiv. DOI: https://doi.org/10.35542/osf.io/2evn3

Siayah, Syarofis; \& Setiawan, Adib Rifqi. (2020, April 13). A Brief Explanation of Science Education. Thesis Commons. DOI: https://doi.org/10.31237/osf.io/wkvsn

Setiawan, Adib Rifqi; \& Ilmiyah, Surotul. (2020, April 13). Multiple Intelligences Based on Neuroscience. Thesis Commons. DOI: https://doi.org/10.31237/osf.io/e9fyu

Setiawan, Adib Rifqi; \& Ilmiyah, Surotul. (2020, April 13). Kecerdasan Majemuk Berdasarkan Neurosains. EdArXiv. DOI: https://doi.org/10.35542/osf.io/rj2fe

Setiawan, Adib Rifqi. (2020, April 9). Islamic Education in Southeast Asia. EdArXiv. DOI: https://doi.org/10.35542/osf.io/dnjqv

Setiawan, Adib Rifqi. (2020, April 9). Islamic Education in Southeast Asia. Thesis Commons. DOI: https://doi.org/10.31237/osf.io/e794d

Ilmiyah, Surotul; \& Setiawan, Adib Rifqi. (2020, April 7). Students' Worksheet for Distance Learning Based on Scientific Literacy in the Topic Coronavirus Disease 2019 (COVID-19). Thesis Commons. DOI: https://doi.org/10.31237/osf.io/fpg4j

Ilmiyah, Surotul; \& Setiawan, Adib Rifqi. (2020, April 7). Students' Worksheet for Distance Learning Based on Scientific Literacy in the Topic Coronavirus Disease 2019 (COVID-19). EdArXiv. DOI: https://doi.org/10.35542/osf.io/wyz5v

Setiawan, Adib Rifqi; \& Ilmiyah, Surotul. (2020, April 7). Lembar Kegiatan Siswa untuk Pembelajaran Jarak Jauh Berdasarkan Literasi Saintifik pada Topik Penyakit Coronavirus 2019 (COVID-19). EdArXiv. DOI: https://doi.org/10.35542/osf.io/h4632

Setiawan, Adib Rifqi. (2020, April 5). The Arrogant One. Thesis Commons. DOI: https://doi.org/10.31237/osf.io/8nmku 
Setiawan, Adib Rifqi. (2020, April 4). Grace Natalie Louisa. SocArXiv. DOI: https://doi.org/10.31235/osf.io/zwf6g

Setiawan, Adib Rifqi. (2020, April 4). Grace Natalie Louisa. Thesis Commons. DOI: https://doi.org/10.31237/osf.io/u3mxv

Setiawan, Adib Rifqi. (2020, April 3). Sharifah Halimah Alaydrus : a female preachers for our time. SocArXiv. DOI: https://doi.org/10.31235/osf.io/zb8qe

Setiawan, Adib Rifqi. (2020, April 2). Desain Pembelajaran untuk Membimbing Siswa Sekolah Dasar dalam Memperoleh Literasi Saintifik. EdArXiv. DOI: https://doi.org/10.35542/osf.io/u59f8

Setiawan, Adib Rifqi. (2020, April 2). What is the Best Way to Analyze Pre-Post Data?. EdArXiv. DOI: https://doi.org/10.35542/osf.io/h4e6q

Setiawan, Adib Rifqi. (2020, April 2). JUPE My Uncut Story. Open Science Framework (OSF). DOI: https://doi.org/10.31219/osf.io/qdxga

Setiawan, Adib Rifqi. (2020, April 1). Syarifah Halimah Alaydrus. Thesis Commons. DOI: https://doi.org/10.31237/osf.io/xbmes

Setiawan, Adib Rifqi. (2020, April 1). Sharifah Halimah Alaydrus. Thesis Commons. DOI: https://doi.org/10.31237/osf.io/fp79c

Setiawan, Adib Rifqi. (2019, October 8). Biografi Clara Ng Perempuan Penulis Asal Indonesia. PsyArXiv. DOI: https://doi.org/10.31234/osf.io/yk8sx

Setiawan, Adib Rifqi. (2019, December 23). Contoh Langkah Pembelajaran Berorientasi Literasi Saintifik. santrimilenial.net. URL: https://santrimilenial.net/contoh-langkahpembelajaran-berorientasi-literasi-saintifik/

Setiawan, Adib Rifqi. (2019, June 14). Deasy Noviyanti, Perempuan Berbadan Defisit Lemak. qureta.com. URL: https://www.qureta.com/next/post/deasy-noviyanti-perempuanberbadan-defisit-lemak

Setiawan, Adib Rifqi. (2018, December 18). Irma Rahma Suwarma. qureta.com. URL: https://www.qureta.com/next/post/irma-rahma-suwarma

Setiawan, Adib Rifqi. (2018, October 05). Karen Armstrong. qureta.com. URL: https://www.qureta.com/next/post/karen-armstrong

Setiawan, Adib Rifqi. (2018, September 17). Lola Zieta Azelien. qureta.com. URL: https://www.qureta.com/next/post/lola-zieta-azelien

Setiawan, Adib Rifqi. (2018, July 16). Rustriningsih, Srikandi Tersisih. qureta.com. URL: https://www.qureta.com/next/post/rustriningsih-srikandi-tersisih

Setiawan, Adib Rifqi. (2018, July 03). Tangis Daniela Hantuchová. qureta.com. URL: https://www.qureta.com/next/post/tangis-daniela-hantuchova

Setiawan, Adib Rifqi. (2018, June 28). Dewi Perssik. qureta.com. URL: https://www.qureta.com/next/post/dewi-perssik

Setiawan, Adib Rifqi. (2018, June 27). Ice. qureta.com. URL: https://www.qureta.com/next/post/ice

Setiawan, Adib Rifqi. (2018, May 24). Fakhrun. qureta.com. URL: https://www.qureta.com/next/post/fakhrun

Setiawan, Adib Rifqi. (2018, April 10). Eny Rochmawati Octaviani: memberikan hiburan, menyuntikkan harapan. Majalah SANTRI, 8: 15-18. URL: https://issuu.com/majalahsantri/docs/majalah_santri_8/17

Setiawan, Adib Rifqi. (2018, April 10). Busana: pemantas raga, pelaras jiwa. Majalah SANTRI, 8: 2627. URL: https://issuu.com/majalahsantri/docs/majalah_santri_8/28 
Setiawan, Adib Rifqi. (2018, April 10). Rosa Amalia Iqony: paduan yakin diri dan rendah hati. Majalah SANTRI, 8: 46. URL:

https://issuu.com/majalahsantri/docs/majalah_santri_8/48

Setiawan, Adib Rifqi. (2018, March 25). Novi Kaka: Sahabat, Panutan, Pembimbing. qureta.com. URL: https://www.qureta.com/next/post/novi-kaka-sahabat-panutan-pembimbing

Setiawan, Adib Rifqi. (2018, March 21). Bidadari di Kesunyian itu Bernama Maria Sharapova. qureta.com. URL: https://www.qureta.com/next/post/bidadari-di-kesunyian-itubernama-maria-sharapova

Setiawan, Adib Rifqi. (2018, March 19). Airin Rachmi Diany, Lilin Penerang Masyarakat Urban. qureta.com. URL: https://www.qureta.com/next/post/airin-rachmi-diany-lilinpenerang-masyarakat-urban

Setiawan, Adib Rifqi. (2018, March 19). Kamu dalam Aku: A Brief Story of Park Bom. qureta.com. URL: https://www.qureta.com/next/post/kamu-dalam-aku-a-brief-story-of-parkbom

Setiawan, Adib Rifqi. (2018, March 19). Guru yang Menyapih: Catatan Perjalanan Pribadi Nong Darol Mahmada. qureta.com. URL: https://www.qureta.com/next/post/guru-yangmenyapih-catatan-perjalanan-pribadi-nong-darol-mahmada

Setiawan, Adib Rifqi. (2018, March 17). Maryam Musfiroh: An Educator for Our Time. qureta.com. URL: https://www.qureta.com/next/post/maryam-musfiroh-an-educator-for-ourtime

Setiawan, Adib Rifqi. (2018, March 15). Eny R. Octaviani. qureta.com. URL: https://www.qureta.com/next/post/eny-r-octaviani

Setiawan, Adib Rifqi. (2018, March 14). Surely You're Joking, Mrs. Ilmy!. qureta.com. URL: https://www.qureta.com/next/post/surely-you-re-joking-mrs-ilmy

Setiawan, Adib Rifqi. (2018, March 14). Meniti Ilmuwati. qureta.com. URL: https://www.qureta.com/next/post/meniti-ilmuwati

Setiawan, Adib Rifqi. (2018, March 12). Clara Ng. qureta.com. URL: https://www.qureta.com/next/post/clara-ng

Setiawan, Adib Rifqi. (2018, March 11). Kisah Kasih Ayah di Balik Mata Najwa. qureta.com. URL: https://www.qureta.com/next/post/kisah-kasih-ayah-di-balik-mata-najwa

Setiawan, Adib Rifqi. (2018, March 11). Rosa Amalia Iqony. qureta.com. URL: https://www.qureta.com/next/post/rosa-amalia-iqony

Setiawan, Adib Rifqi. (2018, March 10). Venice Min. qureta.com. URL: https://www.qureta.com/next/post/venice-min

Setiawan, Adib Rifqi. (2018, March 09). Ketika YoonA Menyaksikan Real Madrid Menghempaskan PSG. qureta.com. URL: https://www.qureta.com/next/post/ketika-yoonamenyaksikan-real-madrid-menghempaskan-psg

Setiawan, Adib Rifqi. (2018, March 09). Kepedulian Airin Rachmi Diany pada Pendidikan. qureta.com. URL: https://www.qureta.com/next/post/kepedulian-airin-rachmidiany-pada-pendidikan

Setiawan, Adib Rifqi. (2018, March 09). Laila Fariha Zein (a.k.a. Uus atau Febi). qureta.com. URL: https://www.qureta.com/next/post/laila-fariha-zein-febi

Setiawan, Adib Rifqi. (2018, March 09). Pantat Perekat Umat. qureta.com. URL: https://www.qureta.com/next/post/pantat-perekat-umat

Setiawan, Adib Rifqi. (2018, March 09). Sisi Religi Grace Natalie. qureta.com. URL: https://www.qureta.com/next/post/sisi-religi-grace-natalie 
Setiawan, Adib Rifqi. (2018, March 09). Asal Usul Nama Via Vallen. qureta.com. URL: https://www.qureta.com/next/post/asal-usul-nama-via-vallen

Setiawan, Adib Rifqi. (2018, March 07). Mengenal Oza Kioza. qureta.com. URL: https://www.qureta.com/next/post/mengenal-oza-kioza

Setiawan, Adib Rifqi. (2018, March 06). Menyoal Vokal Duo Serigala. qureta.com. URL: https://www.qureta.com/next/post/menyoal-vokal-duo-serigala

Setiawan, Adib Rifqi. (2018, March 06). Breast Capital. qureta.com. URL: https://www.qureta.com/next/post/breast-capital

Amatullah; \& Setiawan, Adib Rifqi. (2017, October 10). Nadirsyah Hosen: berkarya sebagai diaspora. Majalah SANTRI, 7: 56-59. URL: https://issuu.com/majalahsantri/docs/santri_edisi_7/58

Setiawan, Adib Rifqi. (2017, June 03). Dari Yuli Hingga Julia. qureta.com. URL: https://www.qureta.com/next/post/dari-yuli-hingga-julia-2

Setiawan, Adib Rifqi. (2017, June 02). Aisha. qureta.com. URL: https://www.qureta.com/next/post/aisha-humaira

Setiawan, Adib Rifqi. (2015, November 10). Kehidupan Asmara Hawking: raga lumpuh, jiwa masih bisa tersentuh. fisikanet.lipi.go.id. URL:

http://www.fisikanet.lipi.go.id/utama.cgi?artikel\&1447145876\&2

Setiawan, Adib Rifqi. (2015, November 07). Dibalik Sampul Buku A Brief History of Time, agar pengetahuan tak hanya dinikmati ilmuwan. fisikanet.lipi.go.id. URL: http://www.fisikanet.lipi.go.id/utama.cgi?artikel\&1446855103\&2

Setiawan, Adib Rifqi. (2015, November 03). Dibalik Nama Besar Albert Einstein: Dari Politik, Asmara, hingga Matematika. fisikanet.lipi.go.id. URL: http://www.fisikanet.lipi.go.id/utama.cgi?artikel\&1446556354\&2

Setiawan, Adib Rifqi. (2015, October 31). Kurir Mikroskopis Alam Semesta bukan debu biasa. fisikanet.lipi.go.id. URL: http://www.fisikanet.lipi.go.id/utama.cgi?artikel\&1446304060\&2

Setiawan, Adib Rifqi. (2015, October 10). 10 Kejutan Subatomik. fisikanet.lipi.go.id. URL: http://www.fisikanet.lipi.go.id/utama.cgi?artikel\&1444577286\&3 